\title{
System Definition Document: Reactor Data Necessary for Modeling Plutonium Disposition in Catawba Nuclear Station Units 1 and 2
}

\author{
R. J. Ellis
}

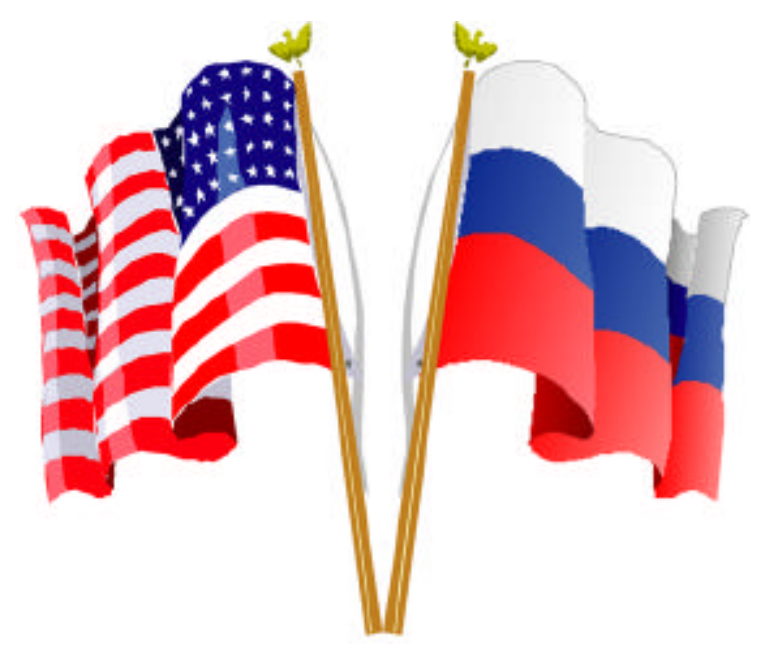

Fissile Materials Disposition Program 


\section{DOCUMENT AVAILABILITY}

Reports produced after January 1, 1996, are generally available free via the U.S. Department of Energy (DOE) Information Bridge.

Web site http://www.osti.gov/bridge

Reports produced before January 1, 1996, may be purchased by members of the public from the following source.

National Technical Information Service

5285 Port Royal Road

Springfield, VA 22161

Telephone 703-605-6000 (1-800-553-6847)

TDD 703-487-4639

Fax 703-605-6900

E-mailinfo@ntis.fedworld.gov

Web site http://www.ntis.gov/support/ordernowabout.htm

Reports are available to DOE employees, DOE contractors, Energy Technology Data Exchange (ETDE) representatives, and International Nuclear Information System (INIS) representatives from the following source.

Office of Scientific and Technical Information

P.O. Box 62

Oak Ridge, TN 37831

Telephone 865-576-8401

Fax 865-576-5728

E-mail reports@adonis.osti.gov

Web site http://www.osti.gov/contact.html

This report was prepared as an account of work sponsored by an agency of the United States Government. Neither the United States Government nor any agency thereof, nor any of their employees, makes any warranty, express or implied, or assumes any legal liability or responsibility for the accuracy, completeness, or usefulness of any information, apparatus, product, or process disclosed, or represents that its use would not infringe privately owned rights. Reference herein to any specific commercial product, process, or service by trade name, trademark, manufacturer, or otherwise, does not necessarily constitute or imply its endorsement, recommendation, or favoring by the United States Government or any agency thereof. The views and opinions of authors expressed herein do not necessarily state or reflect those of the United States Government or any agency thereof. 
ORNL/TM-1999/255

Computational Physics and Engineering Division

\title{
SYSTEM DEFINITION DOCUMENT: REACTOR DATA NECESSARY FOR MODELING PLUTONIUM DISPOSITION IN CATAWBA NUCLEAR STATION UNITS 1 AND 2
}

\author{
R. J. Ellis
}

Date Published: September 2000

Prepared by the

OAK RIDGE NATIONAL LABORATORY

Oak Ridge, Tennessee 37831-6285

managed by

UT-BATTELLE, LLC

for the

U.S. DEPARTMENT OF ENERGY

under contract DE-AC05-00OR22725 
Page Intentionally Blank 


\section{CONTENTS}

Page

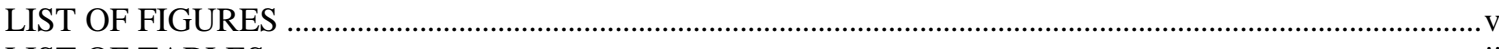

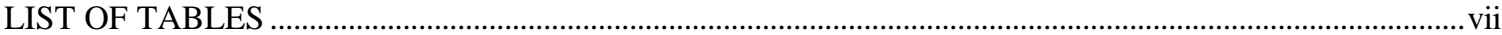

ABSTRACT

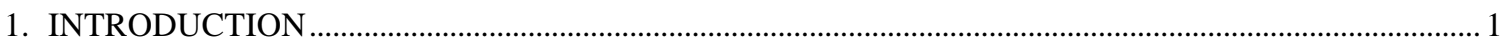

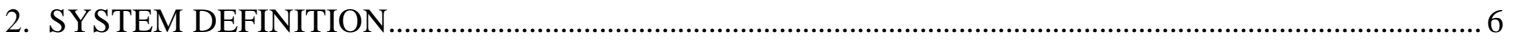

3. FUEL MANAGEMENT STRATEGY

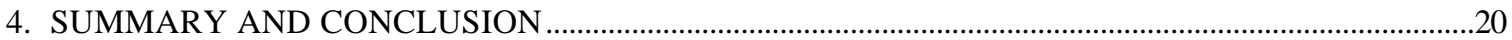

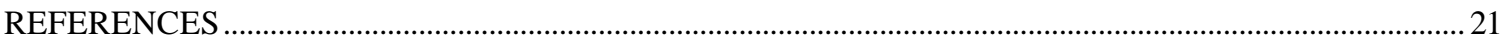


Page Intentionally Blank 


\section{LIST OF FIGURES}

Figure

Page

Catawba Nuclear Station .......................................................................................................

Location of Catawba Nuclear Station....................................................................................... 2

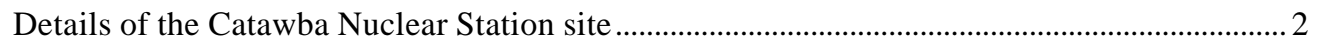

View of the Westinghouse PWR with the 4-loop cooling system.................................................. 3

Cross-sectional 3-D view of a similar Westinghouse PWR ……………………............................ 4

Details of the FCF Mark-BW $17 \times 17$ PWR fuel assembly ........................................................

Standard LEU $\mathrm{UO}_{2}$ assembly (Mark-BW) ........................................................................... 9

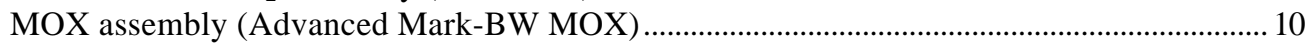

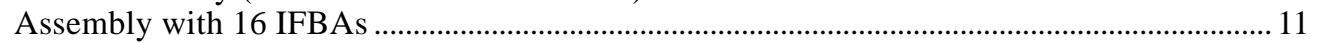

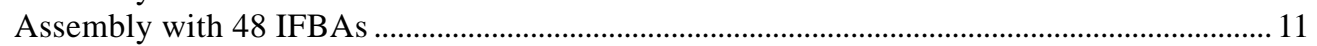

Assembly with 64 IFBAs ................................................................................................. 12

Assembly with 80 IFBAs ................................................................................................. 12

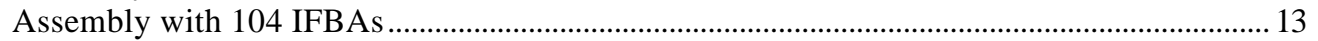

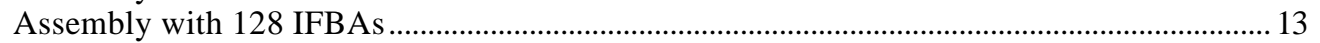

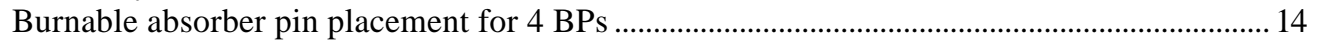

Burnable absorber pin placement for 8 BPs ........................................................................... 14

Burnable absorber pin placement for 12 BPs........................................................................ 15

Burnable absorber pin placement for 16 BPs ..................................................................... 15

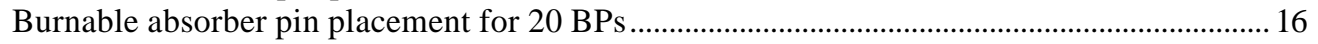

Burnable absorber pin placement for 24 BPs........................................................................ 16

Fuel-loading pattern for equilibrium 40\% MOX core (Catawba Units 1 and 2)....................... 17

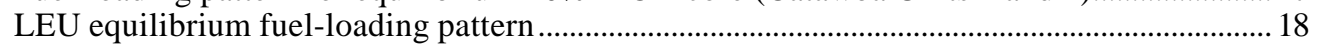

Location of shutdown and control rod clusters in Catawba Units 1 and 2................................ 19 
Page Intentionally Blank 


\section{LIST OF TABLES}

Table

Page

Reactor operating details and conditions for Catawba Nuclear Station ..................................... 6

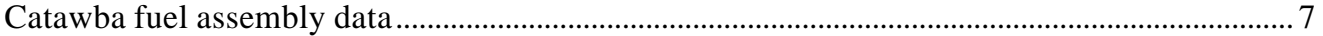

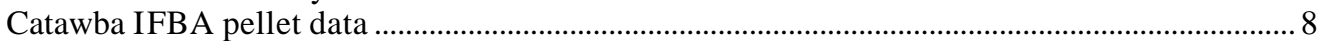

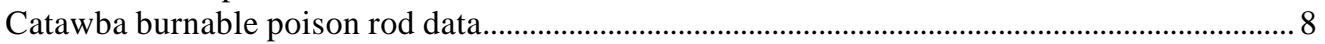

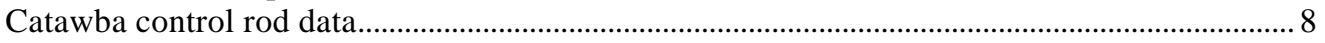

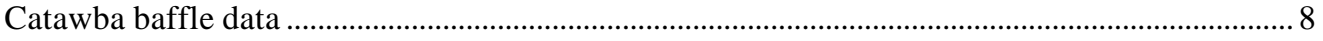

Plutonium content (wt \%) in the MOX fuel assemblies for use at Catawba Nuclear

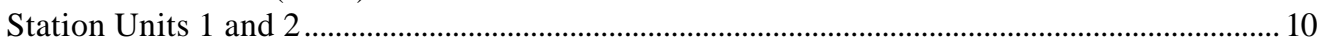


Page Intentionally Blank 


\title{
SYSTEM DEFINITION DOCUMENT: REACTOR DATA NECESSARY FOR MODELING PLUTONIUM DISPOSITION IN CATAWBA NUCLEAR STATION UNITS 1 AND 2
}

\author{
R. J. Ellis
}

\begin{abstract}
The U.S. Department of Energy (USDOE) has contracted with Duke Engineering and Services, Cogema, Inc., and Stone \& Webster (DCS) to provide mixed-oxide (MOX) fuel fabrication and reactor irradiation services in support of USDOE's mission to dispose of surplus weapons-grade plutonium. The nuclear station units currently identified as mission reactors for this project are Catawba Units 1 and 2 and McGuire Units 1 and 2. This report is specific to Catawba Nuclear Station Units 1 and 2, but the details and materials for the McGuire reactors are very similar. The purpose of this document is to present a complete set of data about the reactor materials and components to be used in modeling the Catawba reactors to predict reactor physics parameters for the Catawba site. Except where noted, Duke Power Company or DCS documents are the sources of these data. These data are being used with the ORNL computer code models of the DCS Catawba (and McGuire) pressurized-water reactors.
\end{abstract}

\section{INTRODUCTION}

This system definition document was prepared as part of an Oak Ridge National Laboratory (ORNL) study of the U.S. domestic Duke, Cogema, and Stone \& Webster (DCS) weapons-grade plutonium disposition mixed-oxide (MOX) project. This document pertains to the Duke Power Catawba Nuclear Station Units 1 and 2, located near Rock Hill, South Carolina. A photograph of the Catawba site is shown in Fig. 1. The purpose of this report is to provide and present all of the data required to model the nuclear reactors with ORNL physics codes. These data are either documented information or best-estimate assumptions. ${ }^{1-4}$ The images and maps presented in this report were obtained from the Web sites for Westinghouse, Duke Energy, and Framatome Technologies.

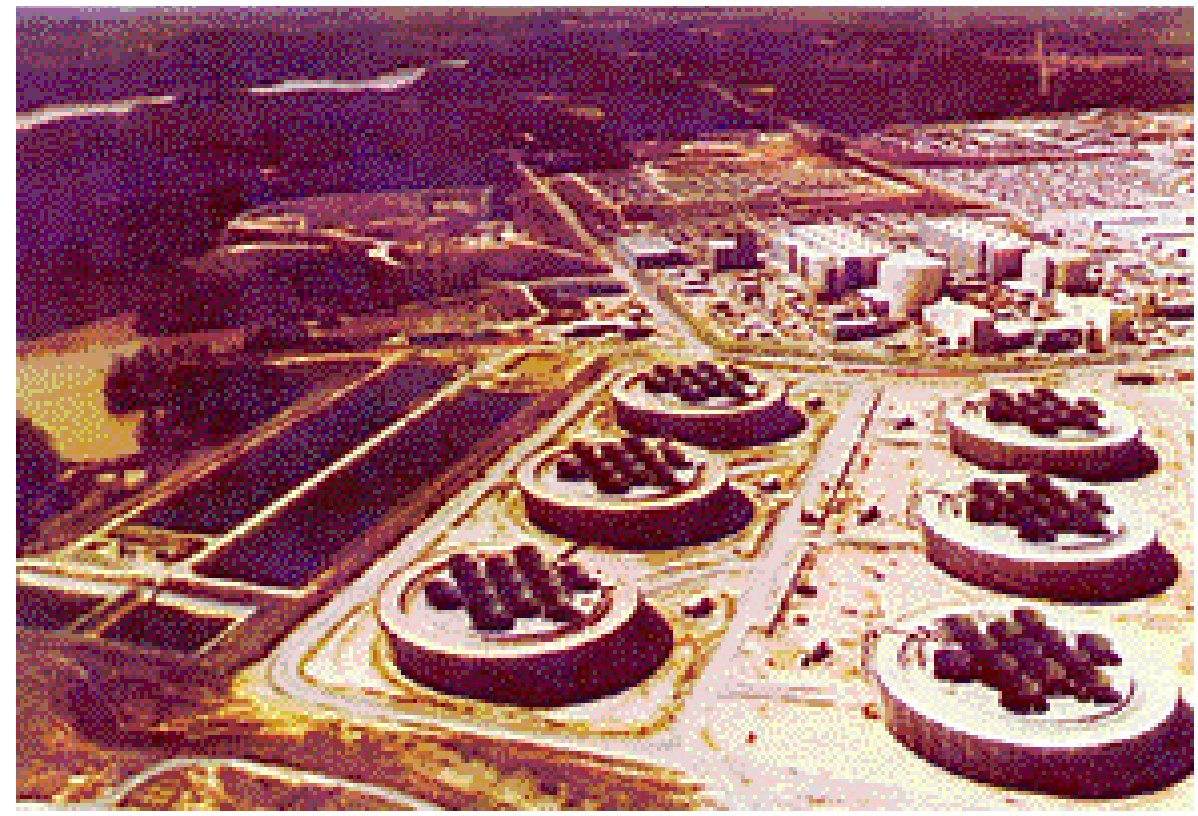

Figure 1. Catawba Nuclear Station. 
Duke Power is responsible for power generation in a large portion of North and South Carolina, as shown in the map in Fig. 2. The Duke Power nuclear stations are indicated on the map as triangles. The Catawba Nuclear Station is 19 miles $(30.6 \mathrm{~km})$ southwest of Charlotte, North Carolina, while McGuire Nuclear Station is north of Charlotte. The Catawba Nuclear Station is in a relatively isolated location. The McGuire units are almost identical to the Catawba Westinghouse units. The region surrounding the Catawba site is depicted in Fig. 3.

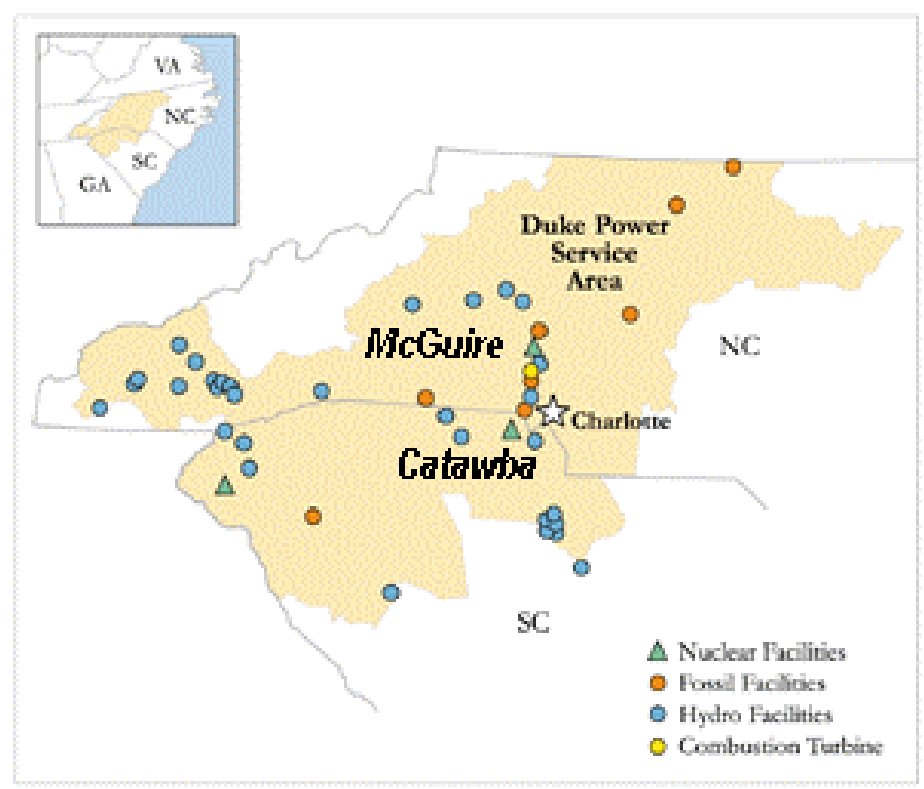

Figure 2. Location of Catawba Nuclear Station.

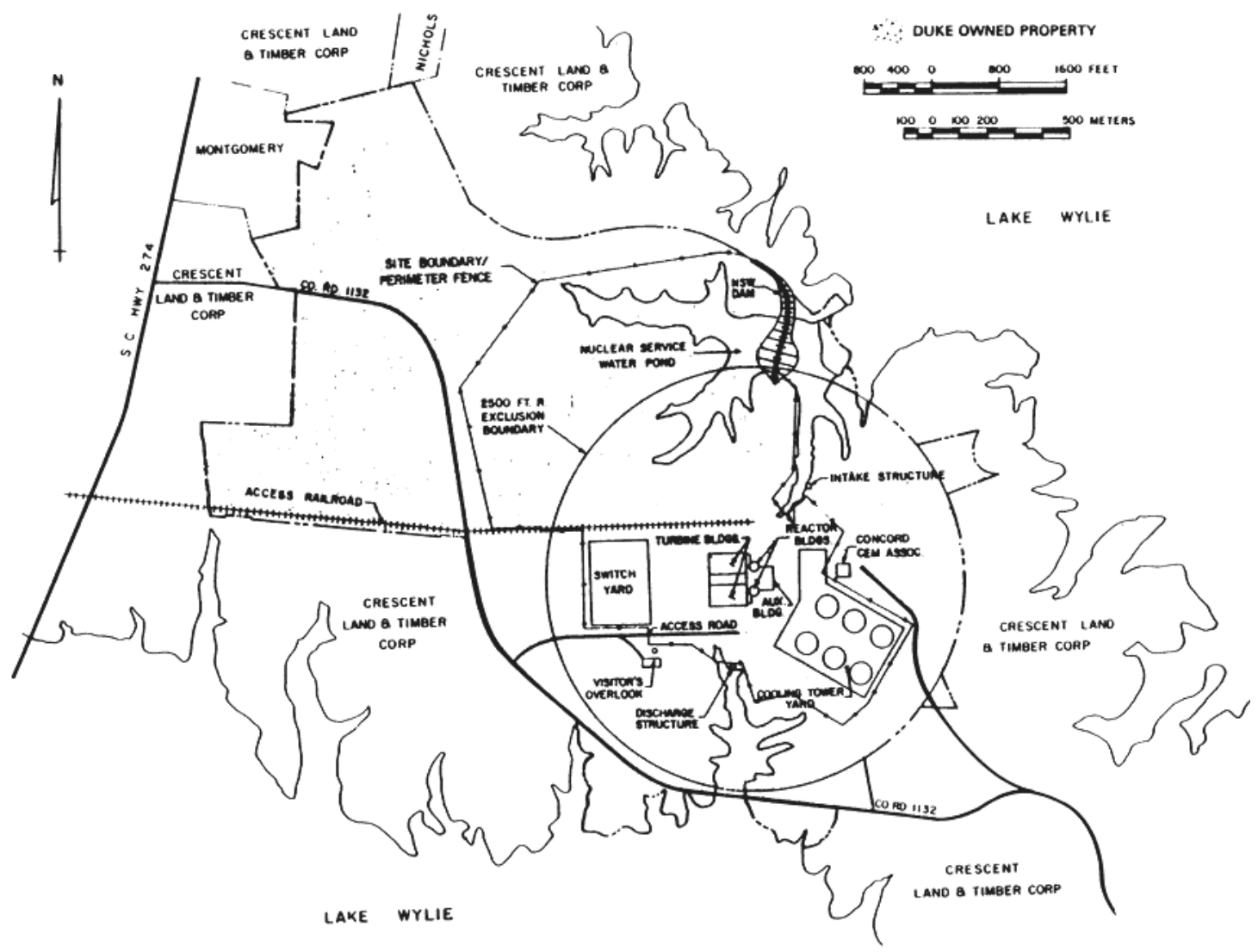

Figure 3. Details of the Catawba Nuclear Station site. 
Catawba Unit 1 began commercial operation on June 29, 1985, and Catawba Unit 2 began commercial operation about a year later, on August 19, 1986. The licenses expire on December 6, 2024, and February 24, 2026, respectively.

The Catawba nuclear reactors are both Westinghouse pressurized-water reactors (PWRs) with 4-loop cooling systems (Fig. 4). The reactors are licensed to produce $3411 \mathrm{MW}(\mathrm{t})$, which currently converts to an electrical capacity of $1129 \mathrm{MW}(\mathrm{e})$. The reactor cores comprise 193 fuel assemblies of the $17 \times 17 \mathrm{design}$, with 264 fuel pins per assembly.

Figure 5 is a three-dimensional (3-D) view of a similar Westinghouse PWR with one-fourth of the core and peripheral components removed. The diagram shows many of the components and regions of the Westinghouse PWR. The control structure ends are prominent at the top of the reactor vessel. The schematic diagram on the right in Fig. 5 identifies the components and devices in the Westinghouse PWR as shown in the open view.

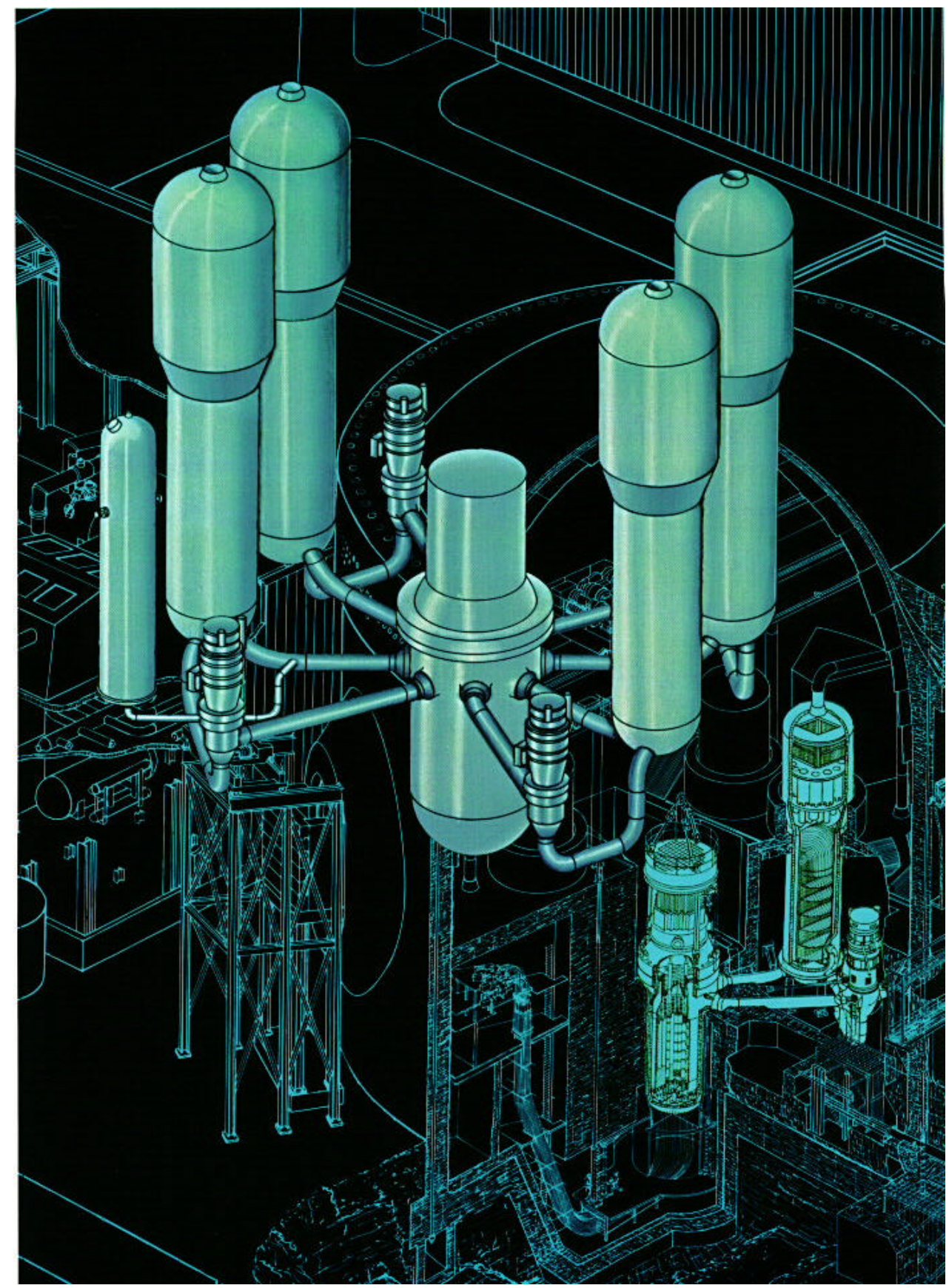

Figure 4. View of the Westinghouse PWR with the 4-loop cooling system. 

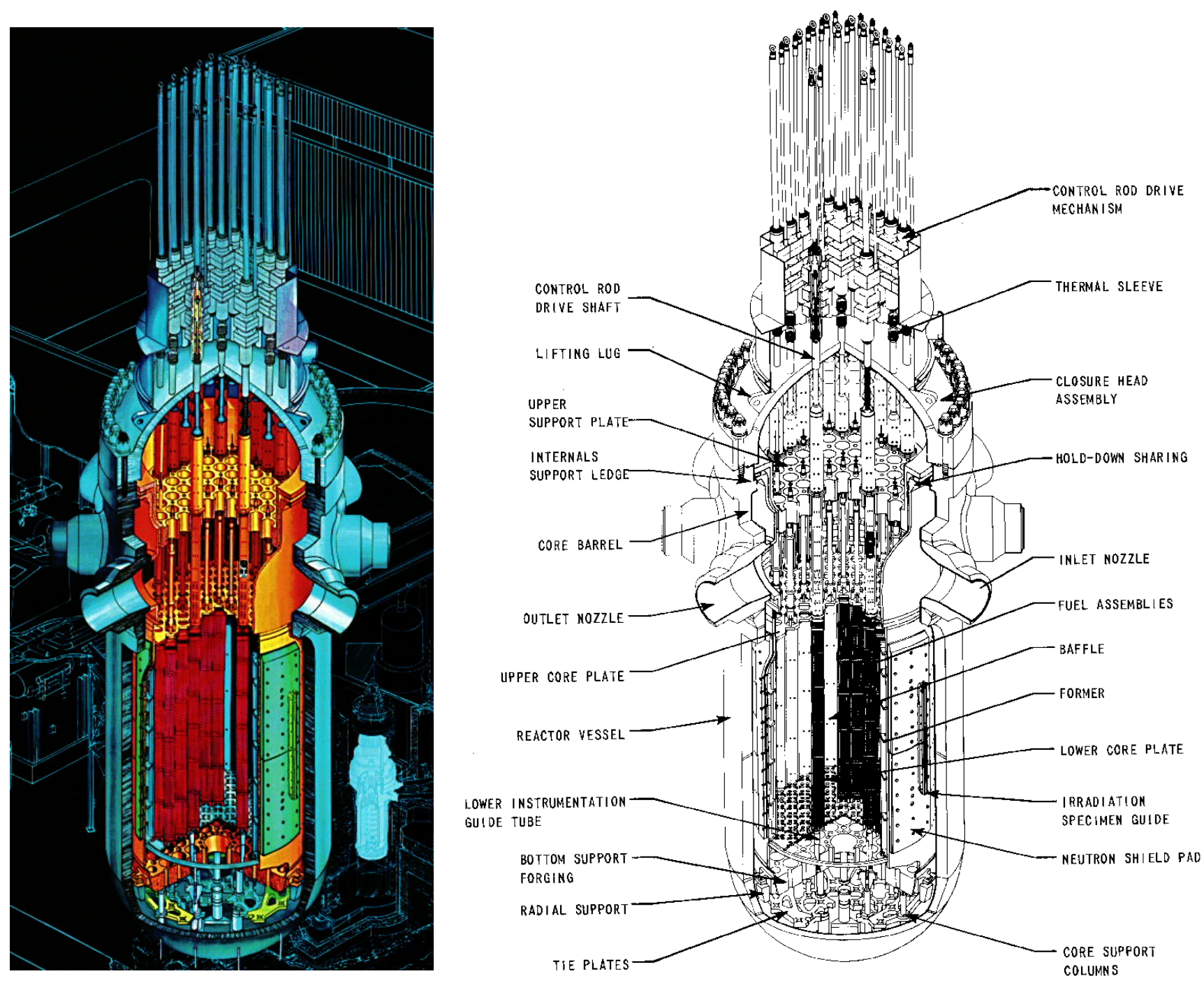

Figure 5. Cross-sectional 3-D view of a similar Westinghouse PWR. 
The fuel assembly "vehicle" for the MOX fuel will be based on the state-of-the-art Framatome/ COGEMA Fuels (FCF) Advanced Mark-BW 17×17 fuel assembly (see Fig. 6). The Mark-BW was developed as replacement fuel for Westinghouse $17 \times 17$ plants and has good service records in the McGuire, Catawba, and Trojan nuclear plants. The Mark-BW is licensed for application in Westinghouse $17 \times 17$ plants to a critical heat flux $(\mathrm{CHF})$ performance level $26 \%$ higher than resident fuel. FCF has delivered more than 1100 Mark-BW fuel assemblies. The new MOX assembly is compatible with the FCF Mark-BW fuel assembly design (currently in McGuire and Catawba nuclear stations). DCS will ensure that the weapons-grade $(\mathrm{WG})$ plutonium MOX fuel assembly will be compatible with existing $17 \times 17$ lowenriched uranium (LEU) fuel assemblies in the reactor core during the lead assembly testing program and then during the production-scale MOX fuel utilization.

The design makes use of European MOX fuel experience of irradiating cores of MOX and LEU fuel assemblies. The advanced micronized master blend (A-MIMAS) process will be used by COGEMA to fabricate WG plutonium $\mathrm{MOX}$ fuel as a ceramic $\mathrm{PuO}_{2}$-and- $\mathrm{UO}_{2}$ fuel pellet with 2 to 5 wt \% fissile plutonium.
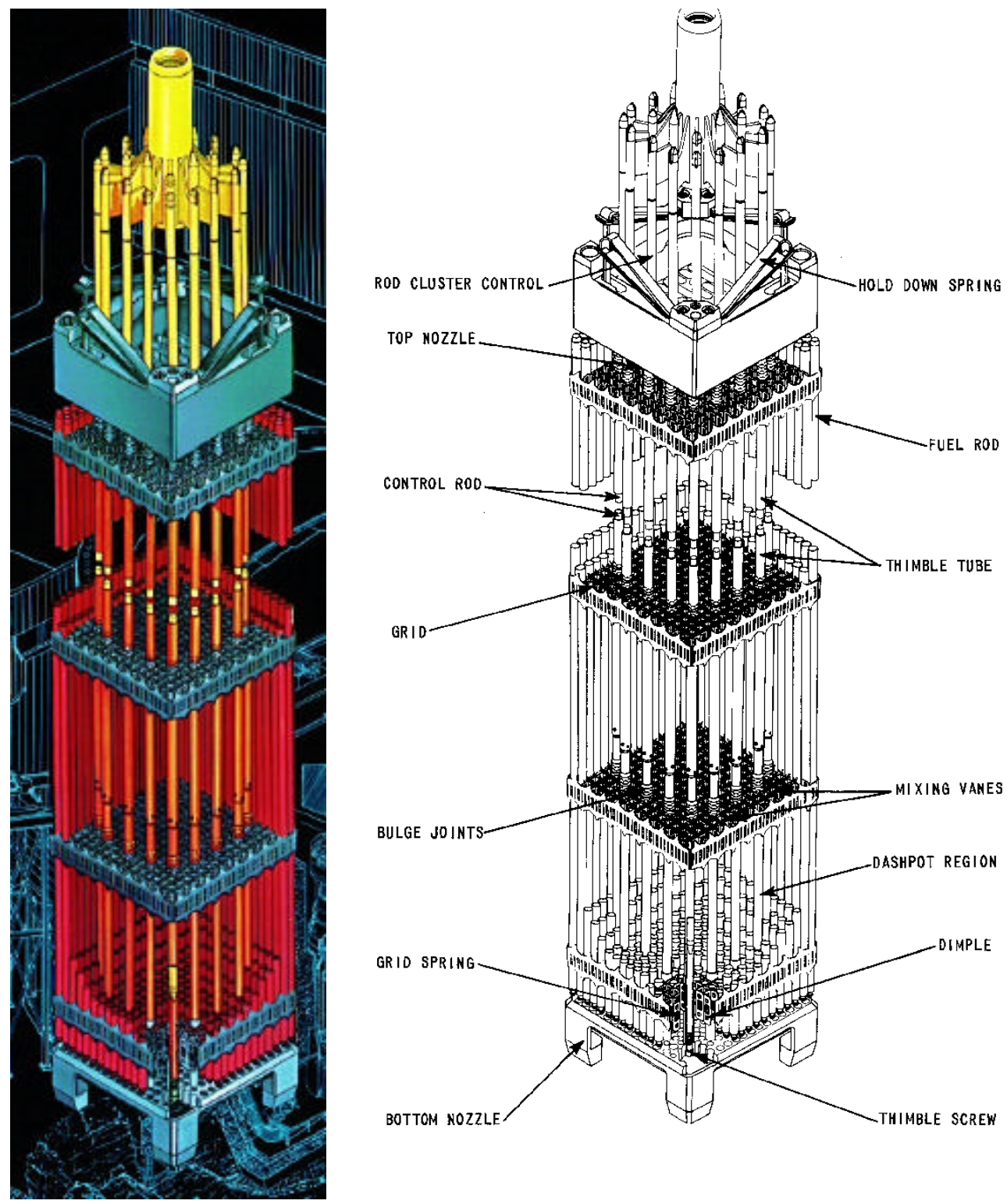

Figure 6. Details of the FCF Mark-BW $17 \times 17$ PWR fuel assembly. 
This process is consistent with the MIMAS process currently being used to fabricate reactor-grade MOX fuel.

The nuclear design of the MOX fuel assembly has to account for differences in the nuclear characteristics between MOX and LEU fuel. The thermal absorption cross section for MOX is quite a bit larger than for LEU and results in lower neutron flux levels in MOX fuel assemblies compared to LEU fuel assemblies. This causes a large thermal neutron flux gradient at the MOX/LEU interfaces, which could result in high-power peaking factors in the outermost pins of the MOX fuel assemblies.

Also, the large thermal absorption and fission cross sections of MOX fuel results in a hardened neutron spectrum that reduces the effectiveness of the thermal neutron absorbers, namely, the soluble boron, the burnable poison (BP) rods, and the control rods. The differences between the two fuel types also produce different depletion behavior. The differences in the fuel characteristics are manageable through careful selection of assembly average plutonium enrichments and enrichment zoning within the MOX fuel assembly. Thus, neutronic differences between the MOX and LEU fuel can be minimized to lessen the perturbations associated with substituting one fuel type for the other.

\section{SYSTEM DEFINITION}

The design details needed for modeling the nuclear reactors at Catawba Nuclear Station Units 1 and 2 include materials and dimensions of reactor components and structures and operating conditions. These actual or assumed data are presented in Tables 1-6. The quantities are presented below both in "engineering" dimensional units and in the International System of Units (SI) or scientific units, as appropriate and neces sary for use in computer code input.

Table 1. Reactor operating details and conditions for the Catawba Nuclear Station

\begin{tabular}{|c|c|c|}
\hline Parameter & Value & SI (where appropriate) \\
\hline Reactor design & Westinghouse PWR, 4-loop cooling system & \\
\hline Thermal power & $3411 \mathrm{MW}(\mathrm{t})$ & \\
\hline Power density & $100.6 \mathrm{~kW} / \mathrm{L}$ (core) & \\
\hline Specific power level & $38.7 \mathrm{~kW} / \mathrm{kgHM}$ & \\
\hline Average linear power/rod & $5.44 \mathrm{~kW} / \mathrm{ft}$ & $17.848 \mathrm{~kW} \mathrm{~m}^{-1}$ \\
\hline Normal peak linear power/rod & $13.58 \mathrm{~kW} / \mathrm{ft}$ & $44.554 \mathrm{~kW} \mathrm{~m}^{-1}$ \\
\hline Core diameter & 132.7 in. & $337.058 \mathrm{~cm}$ \\
\hline \multirow[t]{2}{*}{ Core "barrel" } & ID: 148.0 in. & ID: $375.92 \mathrm{~cm}$ \\
\hline & OD: 152.5 in. & OD: $387.35 \mathrm{~cm}$ \\
\hline Cross-sectional area of core & $96.06 \mathrm{ft}^{2}$ & $8.924 \mathrm{~m}^{2}$ \\
\hline Core height/diameter ratio & 1.09 & \\
\hline Ratio of $\mathrm{H}_{2} \mathrm{O}$ molecules to $\mathrm{U}$ atom & $2.68-2.73$ & \\
\hline Effective flow area for heat transfer & $51.9 \mathrm{ft}^{2}$ & $4.822 \mathrm{~m}^{2}$ \\
\hline Average heat flux & $189400 \mathrm{Btu} / \mathrm{h}-\mathrm{ft}^{2}$ & $59.748 \mathrm{~J} \mathrm{~s}^{-1} \mathrm{~cm}^{-2}$ \\
\hline Maximum heat flux (normal) & $440370 \mathrm{Btu} / \mathrm{h}-\mathrm{ft}^{2}$ & $138.919 \mathrm{~J} \mathrm{~s}^{-1} \mathrm{~cm}^{-2}$ \\
\hline Total thermal flow rate & $1.412 \times 10^{8} \mathrm{lb}_{\mathrm{m}} / \mathrm{h}$ & $1.779 \times 10^{4} \mathrm{~kg} \mathrm{~s}^{-1}$ \\
\hline Effective flow rate for heat transfer & $1.306 \times 10^{8} \mathrm{lb}_{\mathrm{m}} / \mathrm{h}$ & $1.646 \times 10^{4} \mathrm{~kg} \mathrm{~s}^{-1}$ \\
\hline Average coolant velocity along rods & $15.166 \mathrm{ft} / \mathrm{s}$ & $4.623 \mathrm{~m} \mathrm{~s}^{-1}$ \\
\hline Core coolant flow rate & $1.336 \times 10^{8} \mathrm{lb}_{\mathrm{m}} / \mathrm{h}$ & $1.6833 \times 10^{4} \mathrm{~kg} \mathrm{~s}^{-1}$ \\
\hline Average mass velocity & $2.516 \times 10^{6} \mathrm{lb}_{\mathrm{m}} / \mathrm{h}-\mathrm{ft}^{2}$ & $0.3413 \mathrm{~kg} \mathrm{~s}^{-1} \mathrm{~cm}^{-2}$ \\
\hline Number of fuel assemblies in core & 193 & \\
\hline Control rods & 53 & \\
\hline \multirow[t]{2}{*}{ Core inlet coolant temperature } & Unit $1: 556.4^{\circ} \mathrm{F}$ & Unit 1: $291.33^{\circ} \mathrm{C}$ \\
\hline & Unit $2: 558.3^{\circ} \mathrm{F}$ & Unit $2: 292.39^{\circ} \mathrm{C}$ \\
\hline
\end{tabular}


Table 1. (continued)

\begin{tabular}{llc}
\hline \multicolumn{1}{c}{ Parameter } & \multicolumn{1}{c}{ Value } & SI (where appropriate) \\
\hline Average coolant temperature in core & Unit $1: 586.7^{\circ} \mathrm{F}$ & Unit $1: 308.17^{\circ} \mathrm{C}$ \\
& Unit $2: 589.3^{\circ} \mathrm{F}$ & Unit $2: 309.61^{\circ} \mathrm{C}$ \\
Average temperature rise in core & Unit $1: 60.7^{\circ} \mathrm{F}$ & Unit $1: 33.72^{\circ} \mathrm{C}$ \\
& Unit $2: 61.9^{\circ} \mathrm{F}$ & Unit $2: 34.39^{\circ} \mathrm{C}$ \\
Minimum operating pressure & $2250 \mathrm{psia}$ & $15.513 \mathrm{MPa}$ \\
Nominal system pressure & $2280 \mathrm{psia}$ & $15.720 \mathrm{MPa}$ \\
Fraction of heat generated in the fuel & $97.4 \%$ & \\
$\mathrm{UO}_{2}$ feed assemblies (40\% MOX) & 48 & \\
MOX feed assemblies (40\% MOX) & 36 & \\
Fuel cycle duration & $495 \mathrm{~d}(\sim 18$ months) & \\
Assumed capacity factor & $85 \%$ & \\
\hline
\end{tabular}

Table 2. Catawba fuel assembly data

\begin{tabular}{|c|c|c|}
\hline Parameter & Value & SI (where appropriate) \\
\hline Design & FCF Mark-BW, $17 \times 17$, canless & \\
\hline Length & 159.8 in. & $405.8920 \mathrm{~cm}$ \\
\hline Rod length & 152.16 in. & $386.4864 \mathrm{~cm}$ \\
\hline Dimensions & 8.425 in. $\times 8.425$ in. & $21.4 \mathrm{~cm} \times 21.4 \mathrm{~cm}$ \\
\hline Assembly pitch & 8.466 in. & $21.50364 \mathrm{~cm}$ \\
\hline Total number of fuel rods in core & 50,952 & \\
\hline Fuel rods per assembly & 264 & \\
\hline Number of guide tube thimbles & 24 & \\
\hline Number of instrument channels & 1 & \\
\hline Rod pitch & 0.496 in. & $1.25984 \mathrm{~cm}$ \\
\hline Cladding material & M5 or Zircaloy-4 (Zircaloy-4 ${ }^{a}$ ) & \\
\hline Cladding OD & $0.374 \mathrm{in.}$ & $0.94996 \mathrm{~cm}$ \\
\hline Cladding ID & 0.329 in. & $0.83566 \mathrm{~cm}$ \\
\hline Cladding thickness & 0.0225 in. $\left(0.024^{a}\right)$ & $0.05715 \mathrm{~cm}(0.06096)$ \\
\hline Cladding gas gap (radial) & $0.00325 \mathrm{in}$ & $0.00826 \mathrm{~cm}$ \\
\hline Fuel pellet diameter & 0.3225 in. $\left(0.3195^{a}\right)$ & $0.81915 \mathrm{~cm}(0.81153 \mathrm{~cm})$ \\
\hline Guide thimble OD & 0.482 in. & $1.22428 \mathrm{~cm}$ \\
\hline Guide thimble ID & $0.450 \mathrm{in.}$ & $1.14300 \mathrm{~cm}$ \\
\hline Guide thimble material & Zircaloy-4 & \\
\hline \multirow[t]{2}{*}{ Instrument thimble OD } & Upper: 0.482 in. & $1.22428 \mathrm{~cm}$ \\
\hline & Lower: 0.429 in. & $1.08966 \mathrm{~cm}$ \\
\hline \multirow[t]{2}{*}{ Instrument thimble ID } & Upper: 0.450 in. & $1.14300 \mathrm{~cm}$ \\
\hline & Lower: 0.397 in. & $1.00838 \mathrm{~cm}$ \\
\hline Instrument thimble material & Zircaloy-4 & \\
\hline \multirow{2}{*}{ Grid spacer material per core } & 2 end grids: Inconel-718 (782 lb) & End: $354.71 \mathrm{~kg}$ \\
\hline & $\begin{array}{l}6 \text { intermediate grids: Zircaloy-4 } \\
(2928 \mathrm{lb})\end{array}$ & Intermed: $1328.12 \mathrm{~kg}$ \\
\hline Heavy metal (HM) loading/assembly & $463.3 \mathrm{~kg}$ & \\
\hline Active stack length (cold dimension) & 144 in. & $365.76 \mathrm{~cm}$ \\
\hline Fuel pellet material & $\begin{array}{l}\mathrm{PuO}_{2}+\text { depleted } \mathrm{UO}_{2} \text { (ceramic, } \\
\text { sintered) }\end{array}$ & \\
\hline Fuel pellet length & 0.400 in. (chamfered) (Mk-BW) & $1.016 \mathrm{~cm}$ \\
\hline $\begin{array}{l}\text { Volume reduction (pellet chamfer and } \\
\text { dish) }\end{array}$ & $1.0 \%$ & \\
\hline Pellet theoretical density & $95 \%\left(96 \%^{a}\right)$ & \\
\hline Weight of fuel if $\mathrm{UO}_{2}$ & $220,213 \mathrm{lb}$ & $99,887.0 \mathrm{~kg}$ \\
\hline Cladding weight & $56,841 \mathrm{lb}$ (of Zircaloy-4) & $25,782.7 \mathrm{~kg}$ \\
\hline
\end{tabular}

${ }^{a}$ Reported in the Catawba Final Safety Analysis Report (FSAR). 
Table 3. Catawba IFBA pellet data

\begin{tabular}{lll}
\hline \multicolumn{1}{c}{ Parameter } & \multicolumn{1}{c}{ Value } & \multicolumn{1}{c}{ SI } \\
\hline IFBA absorber material & $\begin{array}{l}\text { Zirconium diboride, } \mathrm{ZrB}_{2} \\
\text { (enhanced to } 30 \mathrm{wt} \% \mathrm{in}^{10} \mathrm{~B} \text { to B) }\end{array}$ & \\
Absorber density & $0.061 \mathrm{lb} / \mathrm{in}^{3}$ & $1.688 \mathrm{~g} \mathrm{~cm}^{-3}$ \\
Coating thickness & $1.575 \mathrm{mils}$ & $0.0040 \mathrm{~cm}$ \\
\hline
\end{tabular}

Table 4. Catawba burnable poison rod (BPR) data

\begin{tabular}{llc}
\hline \multicolumn{1}{c}{ Parameter } & \multicolumn{1}{c}{ Value } & \multicolumn{1}{c}{ SI } \\
\hline BPR absorber material & Boron carbide/alumina matrix, $\mathrm{Ab}_{2} \mathrm{O}_{3}-\mathrm{B}_{4} \mathrm{C}$ & \\
Boron content & Variable & \\
Rod OD & 0.381 in. & $0.96774 \mathrm{~cm}$ \\
Cladding material & Stainless steel, SS-304L & $0.06350 \mathrm{~cm}$ \\
Cladding thickness & 0.025 in. $^{a}$ & 0.035 \\
\hline
\end{tabular}

${ }^{a}$ This value was estimated; no Catawba data were available.

Table 5. Catawba control rod data

\begin{tabular}{|c|c|c|}
\hline Parameter & Value & SI \\
\hline Control rod design & Hybrid $\mathrm{B}_{4} \mathrm{C}$ & \\
\hline Absorber material & $\mathrm{B}_{4} \mathrm{C}$ & \\
\hline Number of control rod clusters & 53 & \\
\hline Number of absorber rods/cluster & 24 & \\
\hline Absorber diameter & $0.294 \mathrm{in}$ & $0.74676 \mathrm{~cm}$ \\
\hline Absorber density & $0.064 \mathrm{lb} / \mathrm{in}^{3}$ & $1.7715 \mathrm{~g} \mathrm{~cm}^{-3}$ \\
\hline Rod tip material & Ag-In-Cd (80 wt \%, 15 wt $\%, 5$ wt $\%)$ & \\
\hline Tip diameter & 0.301 in. & $0.76454 \mathrm{~cm}$ \\
\hline Tip length & 40 in. & $101.60 \mathrm{~cm}$ \\
\hline Tip density & 0.367 lb/in. ${ }^{3}$ & $10.159 \mathrm{~g} \mathrm{~cm}^{-3}$ \\
\hline Cladding material & Stainless steel 304L and 316, cold worked & \\
\hline Cladding thickness & $0.0385 \mathrm{in}$. & $0.09779 \mathrm{~cm}$ \\
\hline Full length dry weight (per assembly) & $94 \mathrm{lb}$ & $42.638 \mathrm{~kg}$ \\
\hline Absorber length & 142 in. & $360.68 \mathrm{~cm}$ \\
\hline
\end{tabular}

Table 6. Catawba reactor core baffle data

\begin{tabular}{clc}
\hline \multicolumn{1}{c}{ Parameter } & \multicolumn{1}{c}{ Value } & SI \\
\hline Baffle material & Carbon steel & \\
Baffle thickness & 1.125 in. & $2.8575 \mathrm{~cm}$ \\
\hline
\end{tabular}


Figure 7 is a schematic cross-sectional view of the $17 \times 17$ Mark-BW fuel assembly with standard LEU fuel. The locations of the guide thimble tubes and the central instrument tube are shown.

Figure 8 is a similar schematic for the Advanced Mark-BW fuel assembly for MOX fuel. The high peaking factors in MOX fuel assemblies placed in the high flux levels near the LEU assemblies are minimized by reducing the enrichment in the outermost fuel pins in the MOX assemblies compared to the enrichment in the innermost fuel pins.

DCS has selected a three-zone design consistent with Framatome's experience in Europe. The assembly average plutonium enrichments of the MOX fuel assemblies were chosen to minimize the peaking and also to improve the interchangeability of the MOX and LEU fuel. This was accomplished by establishing MOX fuel assembly average enrichments of 4.07 and $4.37 \mathrm{wt} \%$ plutonium (see Table 7) (based on the distribution of MOX fuel pins with three different levels of plutonium content). These MOX fuel assemblies produce about the same equivalent energy as the LEU fuel assemblies used in the 18-month fuel cycles at the McGuire, Catawba, and North Anna nuclear stations. The isotopic composition vector of the WG plutonium in the MOX fuel is $93.6 \%{ }^{239} \mathrm{Pu}, 5.9 \%{ }^{240} \mathrm{Pu}, 0.4 \%{ }^{241} \mathrm{Pu}$, and $0.1 \%{ }^{242} \mathrm{Pu}$. The $\mathrm{UO}_{2}$ component of the MOX fuel is assumed to have an enrichment of $0.25 \mathrm{wt} \%{ }^{235} \mathrm{U}$.

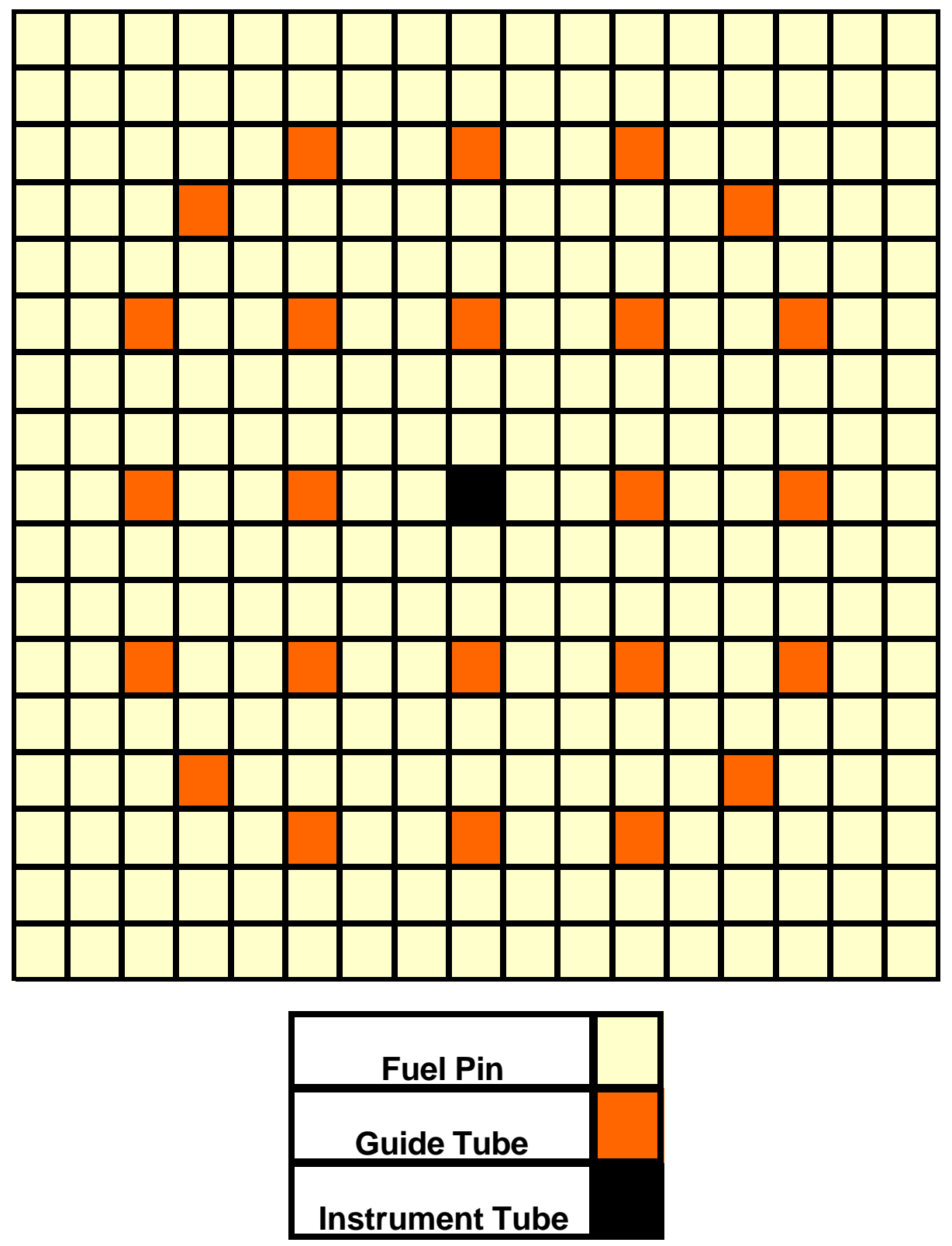

Figure 7. Standard LEU UO $\mathrm{O}_{2}$ assembly (Mark-BW). 


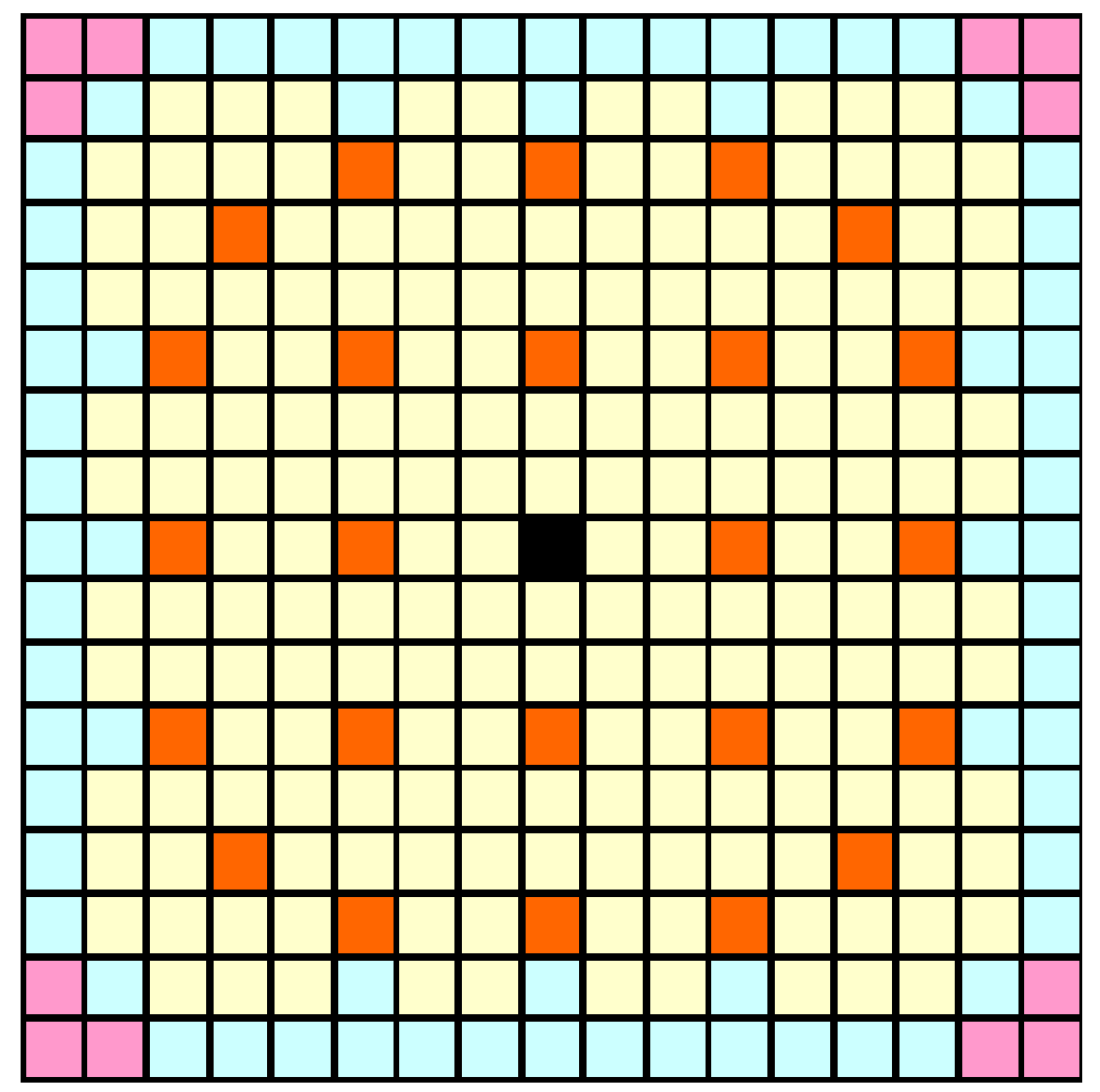

\begin{tabular}{|c|}
\hline High wt \% Pu \\
\hline Medium wt \% Pu \\
\hline Low wt \% Pu \\
\hline Guide Tubes \\
\hline Instrument Tube \\
\hline
\end{tabular}

Figure 8. MOX assembly (Advanced Mark-BW MOX).

Table 7. Fuel pin plutonium content (wt \%) in the MOX fuel assemblies for use at Catawba Nuclear Station Units 1 and 2

\begin{tabular}{lccc}
\hline \multicolumn{1}{c}{ Pin type } & $\begin{array}{c}4.07 \mathrm{wt} \% \\
\text { plutonium }\end{array}$ & $\begin{array}{l}4.37 \mathrm{wt} \% \\
\text { plutonium }\end{array}$ & $\begin{array}{c}\text { Number of fuel } \\
\text { pins of each } \\
\text { plutonium content }\end{array}$ \\
\hline High plutonium content & 4.364 & 4.794 & 184 \\
Medium plutonium content & 3.583 & 3.583 & 68 \\
Low plutonium content & 2.316 & 2.316 & 12 \\
\hline
\end{tabular}

The initial reactivity of a MOX assembly is less than that of the equivalent LEU fuel (which has the same lifetime average reactivity). The reactivity of the MOX fuel decreases at a lower rate than LEU of equivalent enrichment.

Figures 9 to 14 display the various configurations for placement of integral fuel burnable absorbers (IFBAs) in the Mark-BW $17 \times 17$ PWR fuel assemblies. For the DCS plutonium disposition program, it has not been decided whether IFBAs will be placed in MOX fuel assemblies and in $\mathrm{LEU} \mathrm{UO}_{2}$ fuel assemblies or only in the $\mathrm{UO}_{2}$ fuel assemblies. The regions and components of the fuel assemblies are color-coded for clarity.

Figures 15 to 20 display the configurations for placing between 4 and 24 burnable poison rods (BPs) in the Mark-BW fuel assemblies. For clarity, the major regions are color-coded as indicated in the legends. 

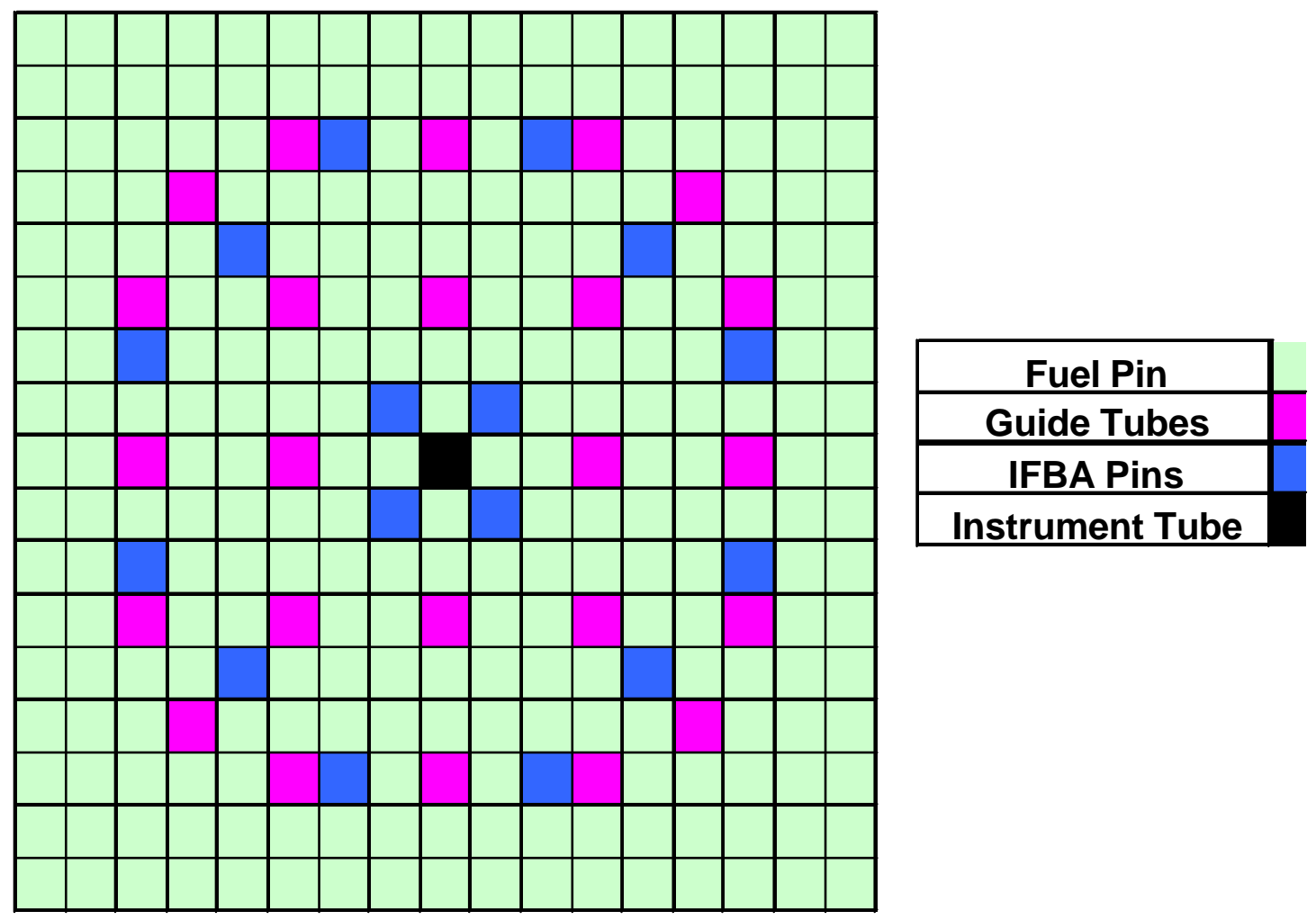

Figure 9. Assembly with 16 IFBAs.

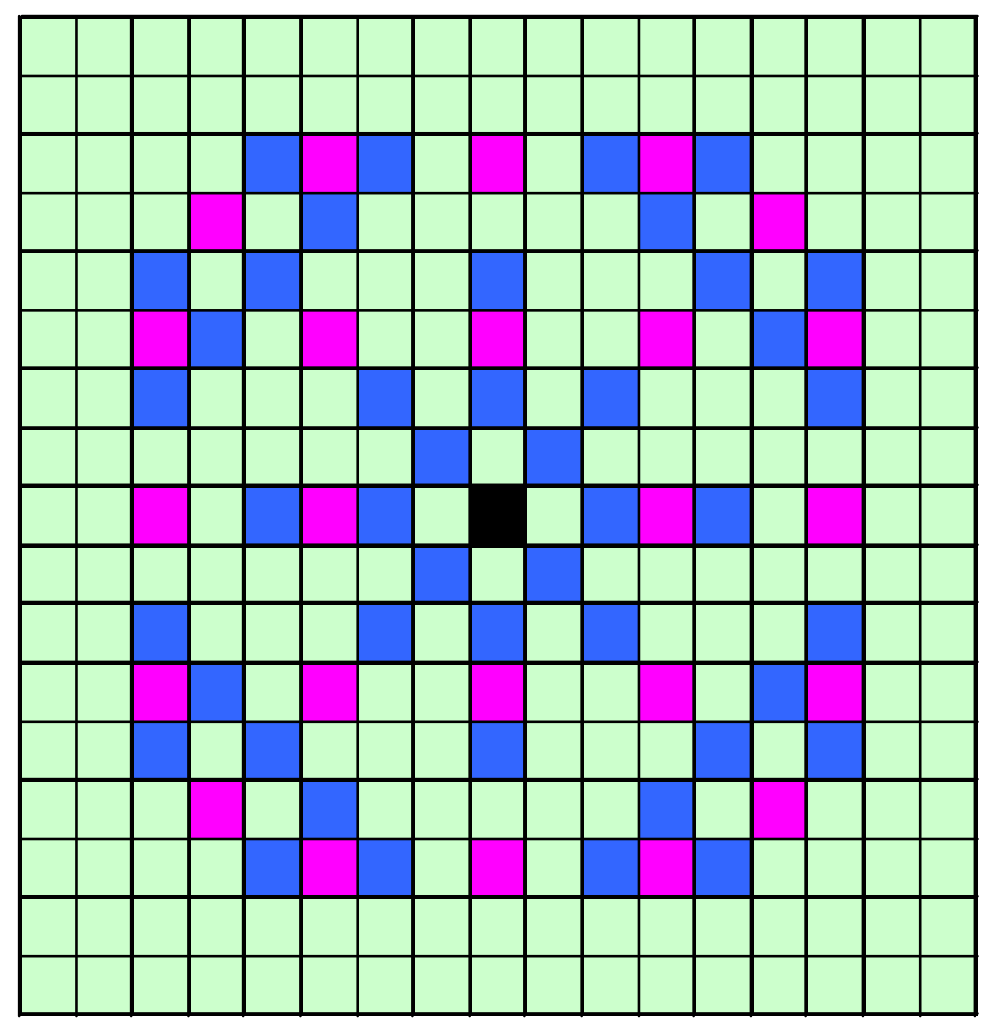

Figure 10. Assembly with 48 IFBAs. 


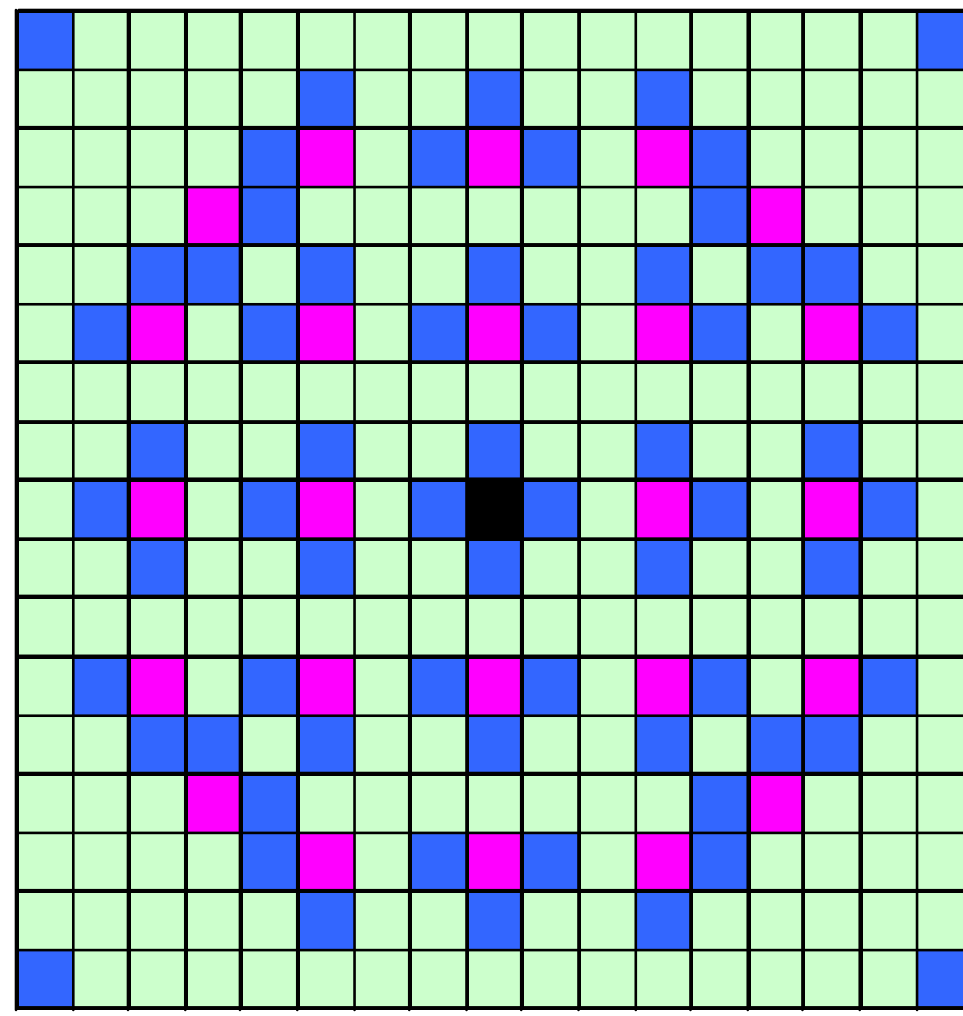

\begin{tabular}{|c|}
\hline Fuel Pin \\
\hline Guide Tubes \\
\hline IFBA Pins \\
\hline Instrument Tube \\
\hline
\end{tabular}

Figure 11. Assembly with 64 IFBAs.

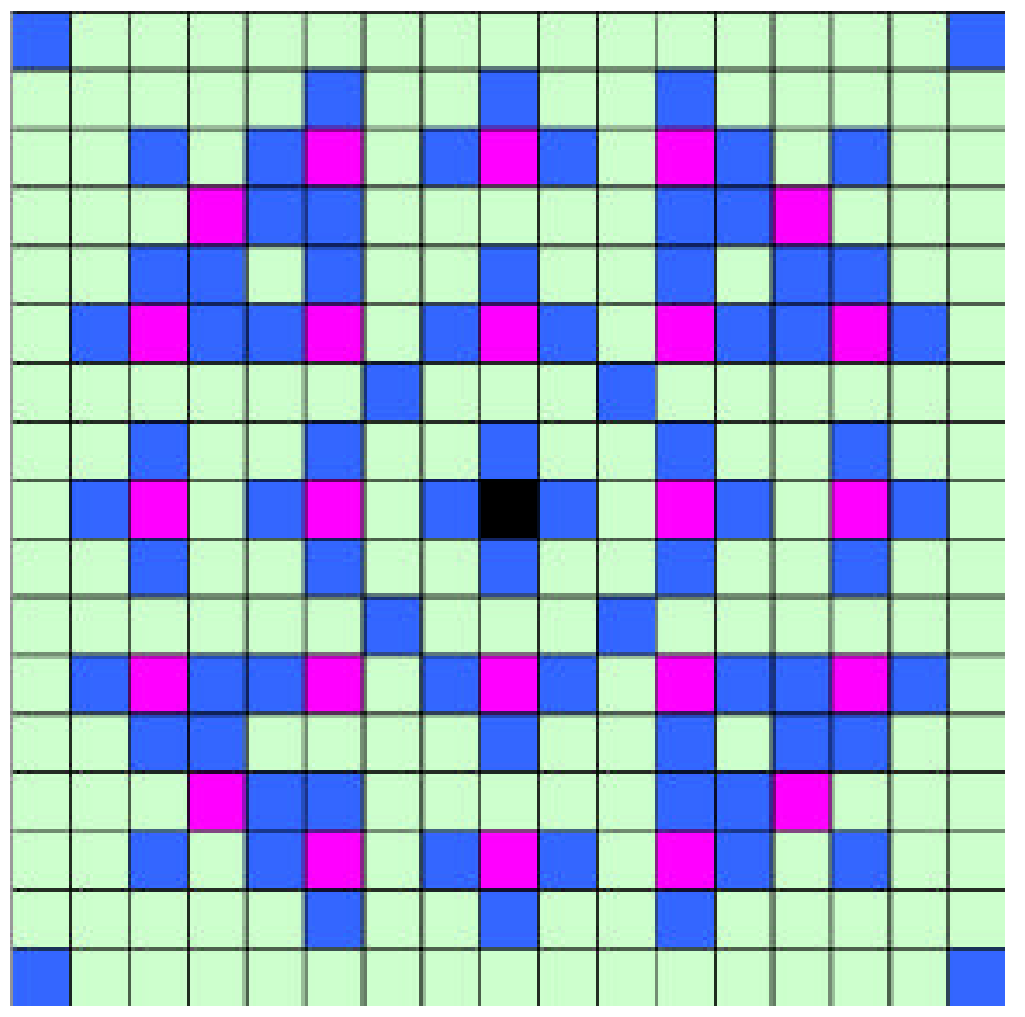

Figure 12. Assembly with 80 IFBAs. 

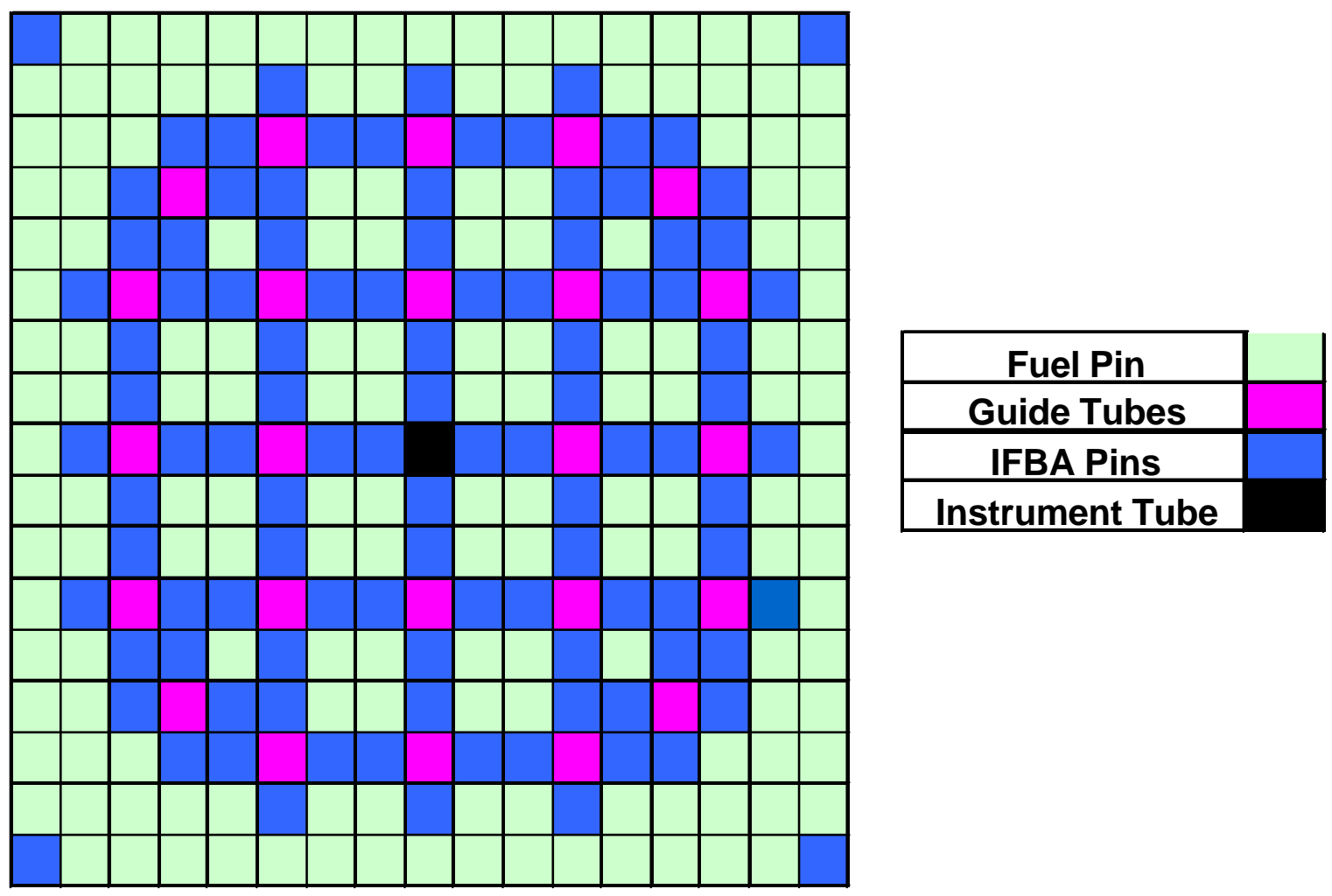

Figure 13. Assembly with 104 IFBAs.

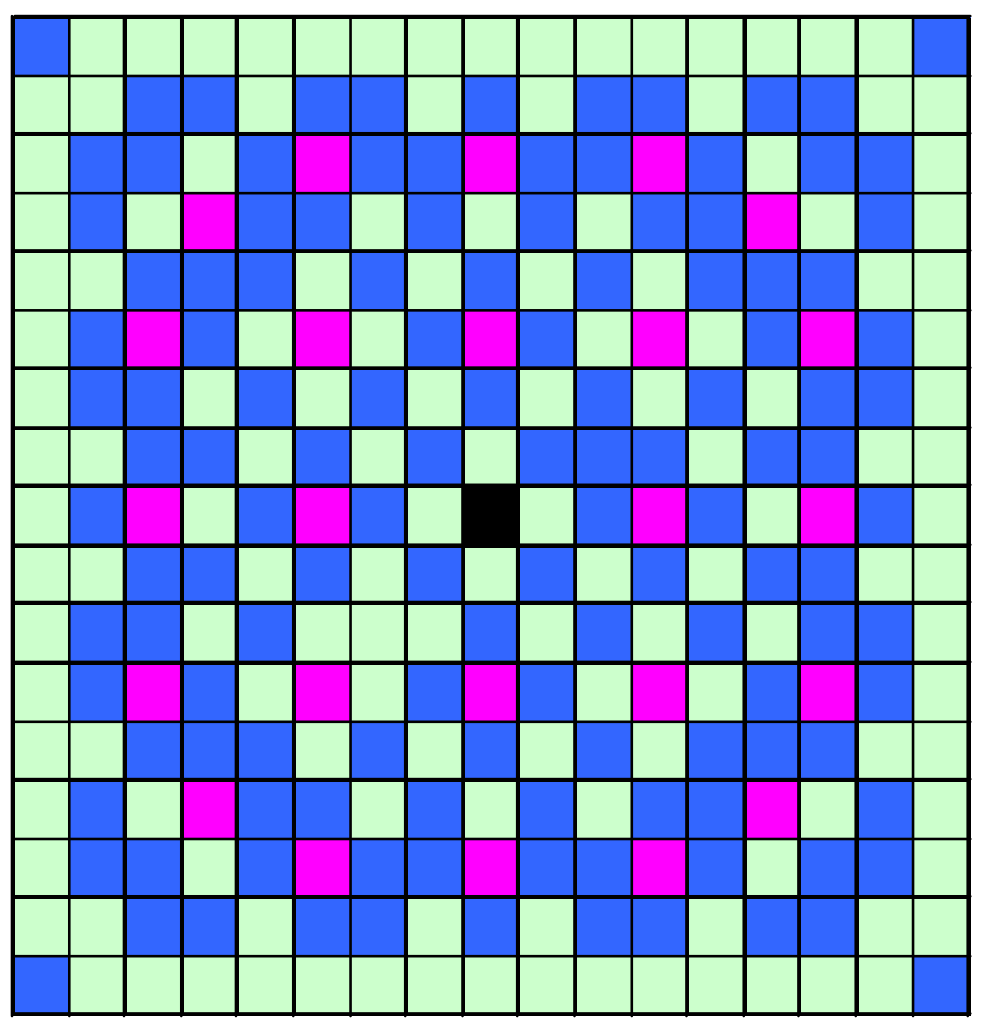

\begin{tabular}{|c|}
\hline Fuel Pin \\
\hline Guide Tubes \\
\hline IFBA Pins \\
\hline Instrument Tube \\
\hline
\end{tabular}

Figure 14. Assembly with 128 IFBAs. 


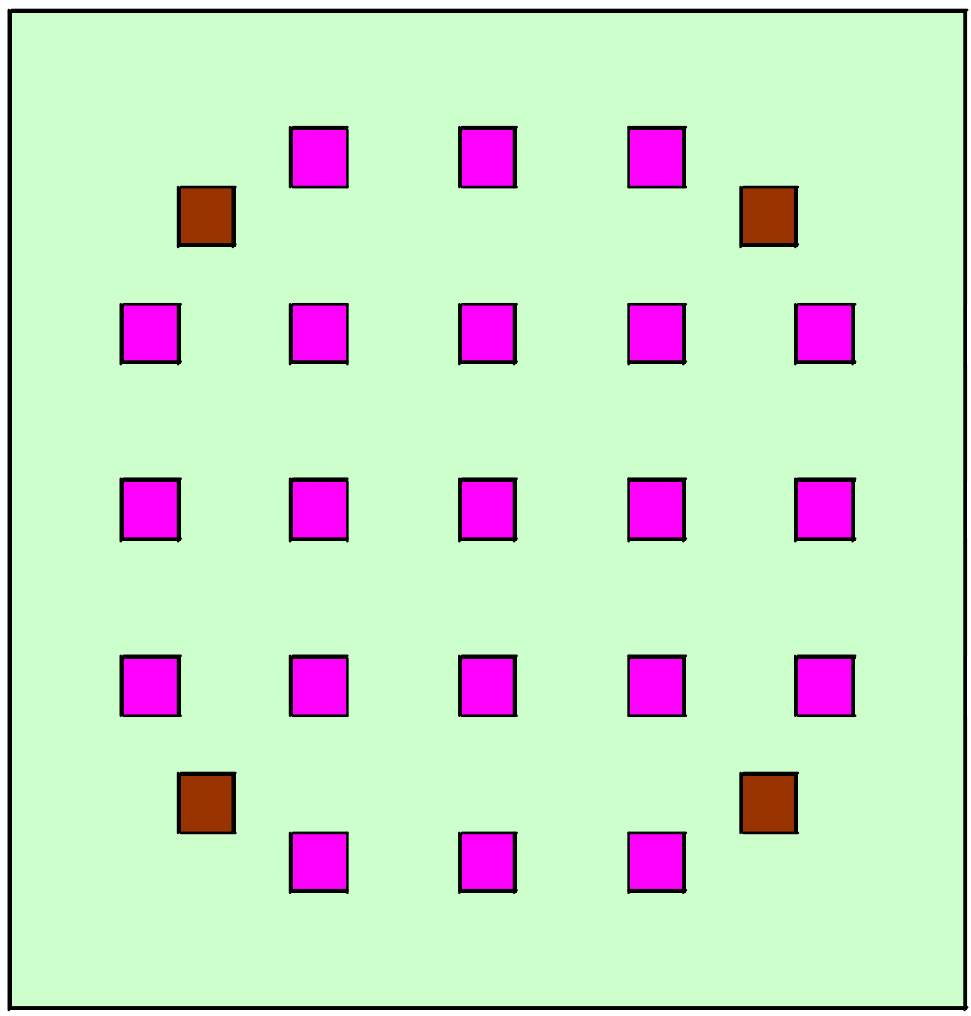

Figure 15. Burnable absorber pin placement for 4 BPs.

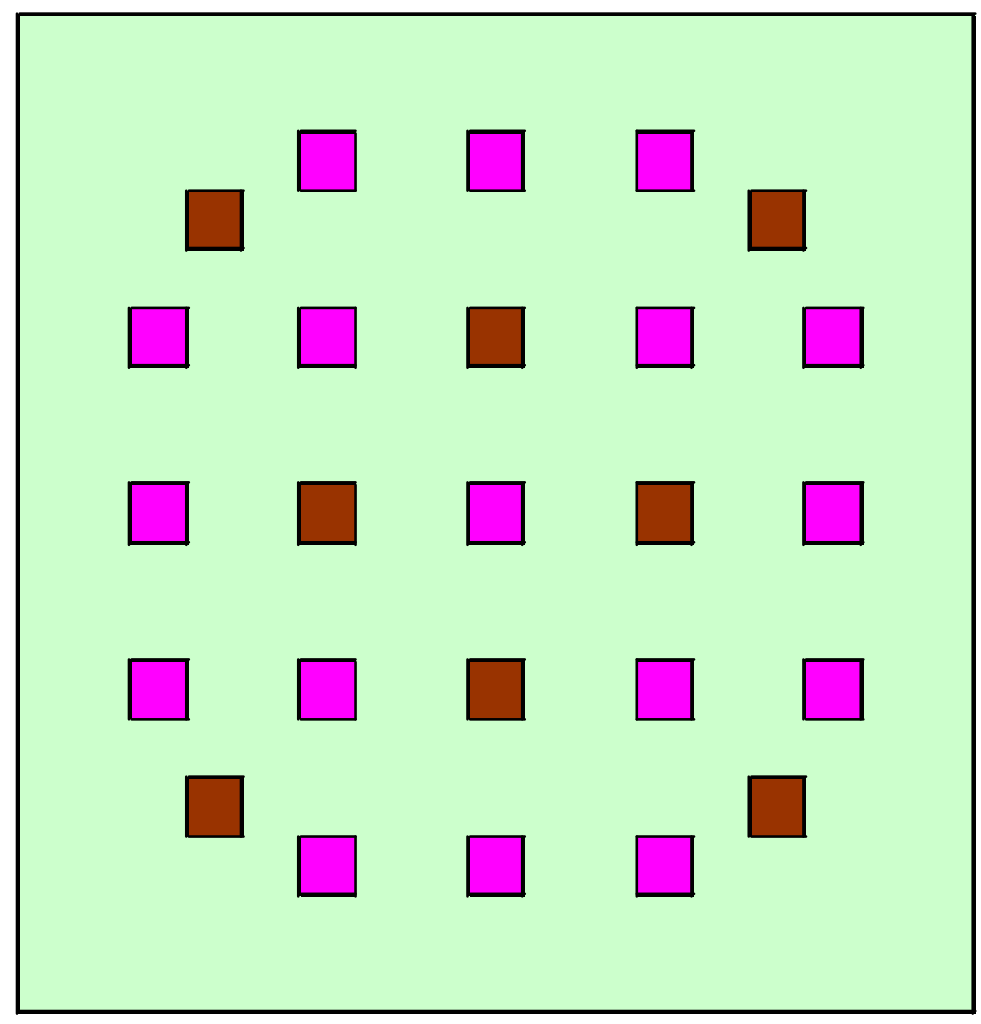

\begin{tabular}{|c|}
\hline Fuel Pin \\
\hline Guide Tube \\
\hline Burn. Abs. Pin (BP) \\
\hline
\end{tabular}

Figure 16. Burnable absorber pin placement for 8 BPs. 


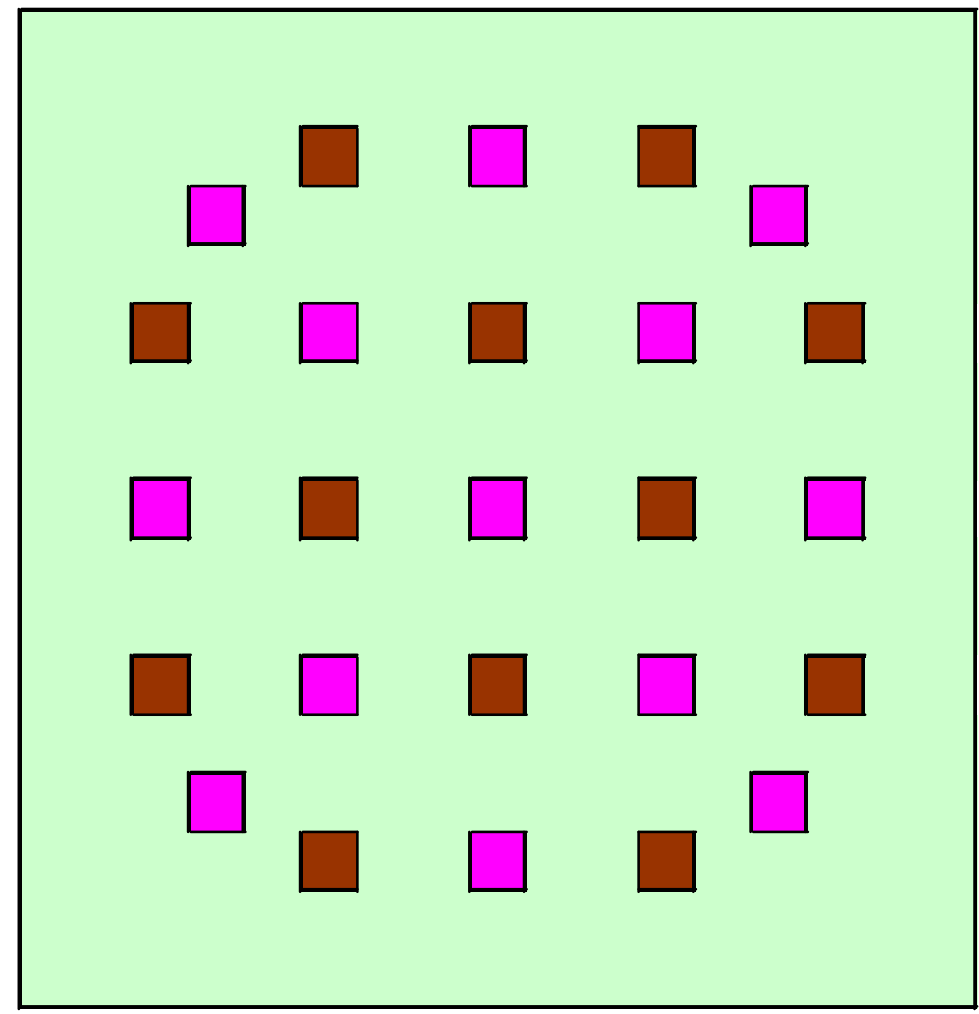

Figure 17. Burnable absorber pin placement for $12 \mathrm{BPs}$.

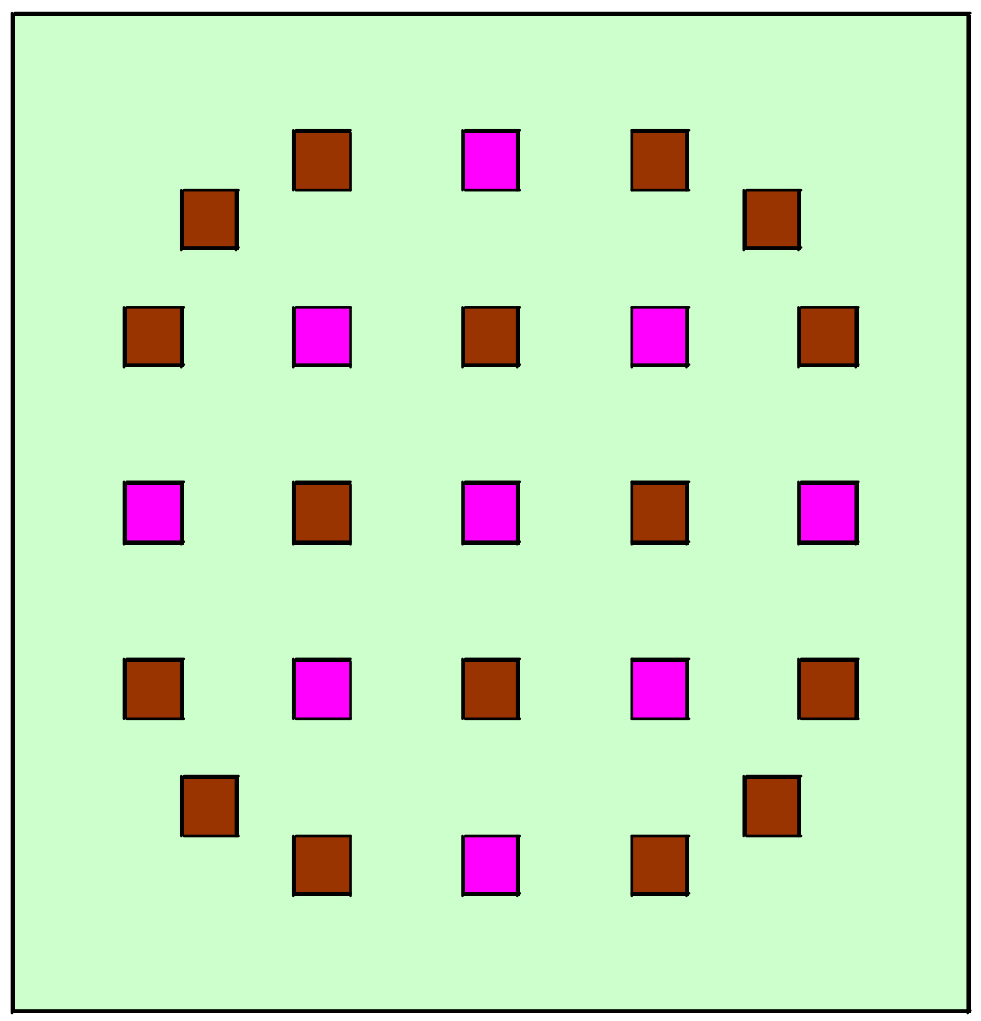

\begin{tabular}{|c|}
\hline Fuel Pin \\
\hline Guide Tube \\
\hline Burn. Abs. Pin (BP) \\
\hline
\end{tabular}

Figure 18. Burnable absorber pin placement for 16 BPs. 


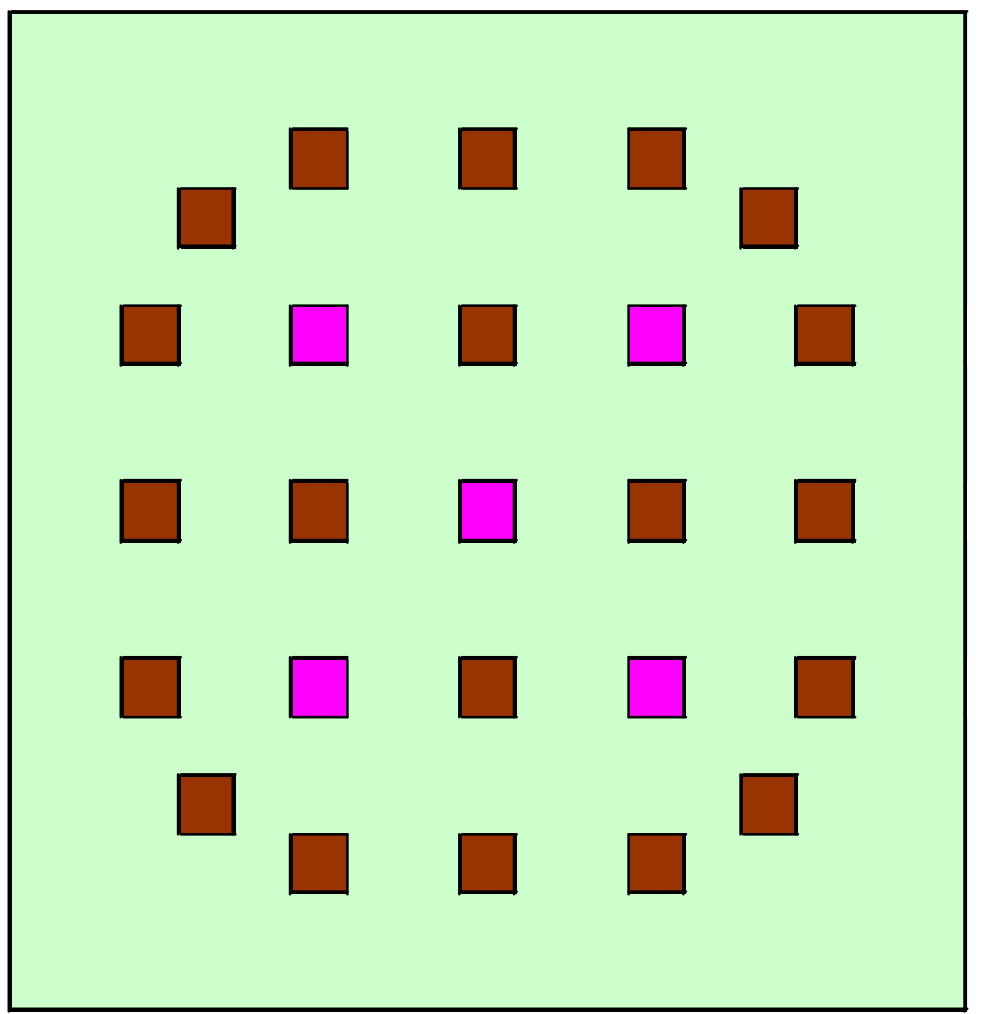

Figure 19. Burnable absorber pin placement for $20 \mathrm{BPs}$.
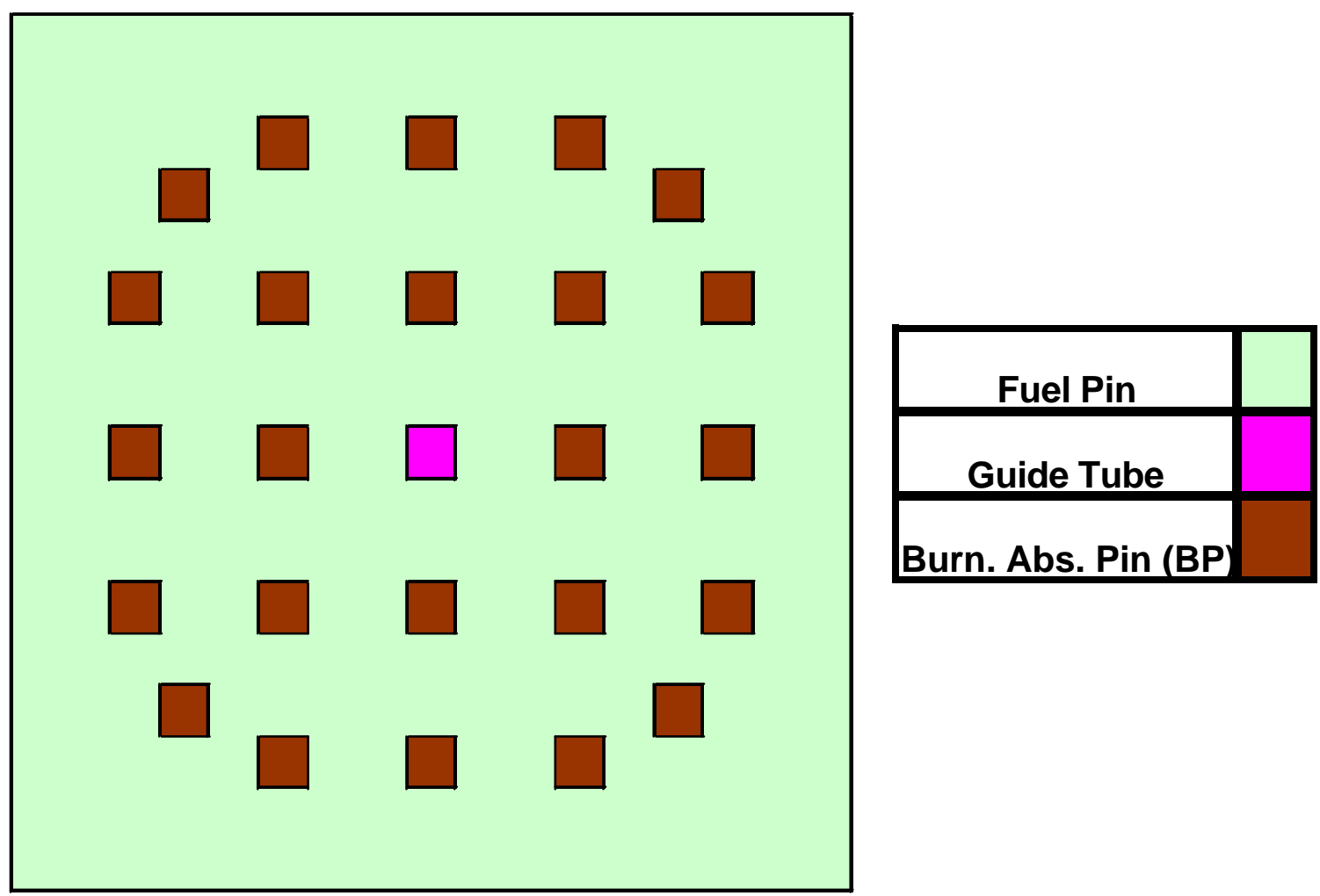

Figure 20. Burnable absorber pin placement for 24 BPs. 


\section{FUEL MANAGEMENT STRATEGY}

The DCS strategy currently calls for an initial irradiation of two MOX lead test assemblies (LTAs). Currently, the MOX LTA irradiation is planned only for the McGuire reactors. After successful irradiation, this will be followed by a controlled transition from an all-LEU fuel core through several partial MOX fuel reloads over several operating cycles. The DCS fuel management plan will irradiate the MOX fuel assemblies for two cycles (average discharge burnup is about 40,000 MWd/kgHM) and LEU fuel assemblies for three cycles. The equilibrium MOX cores at Catawba Units 1 and 2 will have equilibrium MOX core fractions of about 40\%. A plausible loading pattern is shown in Fig. 21 for an equilibrium situation. To maintain the MOX core fraction at $\sim 40 \%$, the number of feed MOX assemblies will have to alternate between 36 and 40 assemblies on subsequent reload cycles. The loading pattern depicted in Fig. 21 represents 36 feed MOX assemblies and 40 once-burned MOX assemblies ( 9 feed MOX assemblies are shown

\begin{tabular}{|c|c|c|c|c|c|c|c|c|}
\hline $\begin{array}{c}3.92 \\
2\end{array}$ & $\begin{array}{c}4.17 \\
20 @ 3.5 \\
u\end{array}$ & 4.24 & $\begin{array}{c}4.40 \\
20 @ 3.0 \\
u\end{array}$ & 4.45 & $\begin{array}{c}4.17 \\
20 @ 4.0 \\
u\end{array}$ & $\begin{array}{c}4.17 \\
128 I F B A \\
u\end{array}$ & 4.31 & \\
\hline $\begin{array}{c}4.17 \\
20 @ 3.5 \\
0\end{array}$ & $\begin{array}{c}4.24 \\
1\end{array}$ & $\begin{array}{c}4.17 \\
24 @ 3.5 \\
0\end{array}$ & 1 & $\begin{array}{c}4.40 \\
24 @ 3.5 \\
0\end{array}$ & 1 & $\begin{array}{c}4.37 \\
16 @ 2.0 \\
0\end{array}$ & $\begin{array}{c}4.24 \\
2\end{array}$ & \\
\hline $\begin{array}{c}4.24 \\
1\end{array}$ & $\begin{array}{c}4.17 \\
24 @ 3.5 \\
0\end{array}$ & 4.24 & $\begin{array}{c}4.07 \\
24 @ 4.0 \\
0\end{array}$ & 4.07 & 4.37 & $\begin{array}{c}4.40 \\
128 \text { IFBA } \\
0\end{array}$ & $\begin{array}{c}4.37 \\
1\end{array}$ & \\
\hline $\begin{array}{c}4.40 \\
24 @ 3.0 \\
0\end{array}$ & 4.24 & $\begin{array}{c}4.07 \\
24 @ 4.0 \\
0\end{array}$ & 4.07 & 4.45 & $\begin{array}{c}4.17 \\
128 \text { IFBA } \\
0\end{array}$ & 4.37 & $\begin{array}{c}3.92 \\
2\end{array}$ & \\
\hline $\begin{array}{c}4.45 \\
1\end{array}$ & $\begin{array}{c}4.40 \\
24 @ 3.5 \\
0\end{array}$ & 4.07 & 4.45 & $\begin{array}{c}4.24 \\
1\end{array}$ & $\begin{array}{c}4.37 \\
20 @ 2.0 \\
0\end{array}$ & 4.24 & & \\
\hline $\begin{array}{c}4.17 \\
24 @ 4.0 \\
0\end{array}$ & 4.37 & 4.37 & $\begin{array}{c}4.17 \\
\text { 128IFBA } \\
0\end{array}$ & $\begin{array}{c}4.37 \\
20 @ 2.0 \\
0\end{array}$ & 4.37 & 4.24 & & $\begin{array}{l}\text { Moxfeed } \\
\text { Oncebuled } \\
\text { Mox }\end{array}$ \\
\hline $\begin{array}{c}4.17 \\
104 \text { IFBA } \\
0\end{array}$ & $\begin{array}{c}4.37 \\
16 @ 2.0 \\
0\end{array}$ & $\begin{array}{c}4.40 \\
\text { 128IFBA } \\
0\end{array}$ & 4.37 & 4.24 & 4.17 & & & $\begin{array}{c}\text { IEUFeed } \\
\text { Oncebured }\end{array}$ \\
\hline 4.37 & $\begin{array}{c}4.24 \\
2\end{array}$ & $\begin{array}{c}4.37 \\
1\end{array}$ & $\begin{array}{c}3.92 \\
2\end{array}$ & & & & & $\begin{array}{l}\text { LEU } \\
\text { Twadulled } \\
\text { IEU }\end{array}$ \\
\hline
\end{tabular}

\begin{tabular}{|c|}
\hline Fuel Enrichment $\left({ }^{235} \mathrm{U}\right.$ or $\left.\mathrm{Pu}\right)$ \\
\hline BPR $@{ }^{10} \mathrm{~B}$ enrichment, or IFBAs \\
\hline Fuel cycles so far \\
\hline
\end{tabular}

Figure 21. Fuel-loading pattern for equilibrium $40 \%$ MOX core (Catawba Units 1 and 2). 
in the $1 / 4$-core schematic). Specific details of the loading patterns, including LEU assembly fuel enrichments, the number of BPRs, and whether or not IFBAs are used, will most likely change as the DCS loading strategies evolve.

Descriptions of transitional loading patterns are not contained in this document. ORNL studies of possible fuel strategies and loading patterns will be performed using the codes HELIOS and NESTLE and will be the subject of a later report. The LEU equilibrium core-loading pattern is shown in Fig. 22; the LEU assemblies are color-coded by fuel irradiation similar to Fig. 21. The indicated control rod banks (A-D) and shutdown rod banks (SA-SE) are discussed and shown in Fig. 23.

The MOX fuel discharge burnup will be within the 45,000-MWd/kgHM MOX discharge fuel burnup experience in Europe at Belgian, Swiss, and German PWRs. The DCS MOX fuel management strategy should result in minimal perturbations to the existing nuclear fuel management scheme at Catawba.

The DCS strategy aims to reach the mission goal of achieving a burnup of at least 20,000 MWd/MTHM and at least one cycle of reactor irradiation on all the MOX fuel assemblies (33 MT plutonium in total) by the end of 2022.

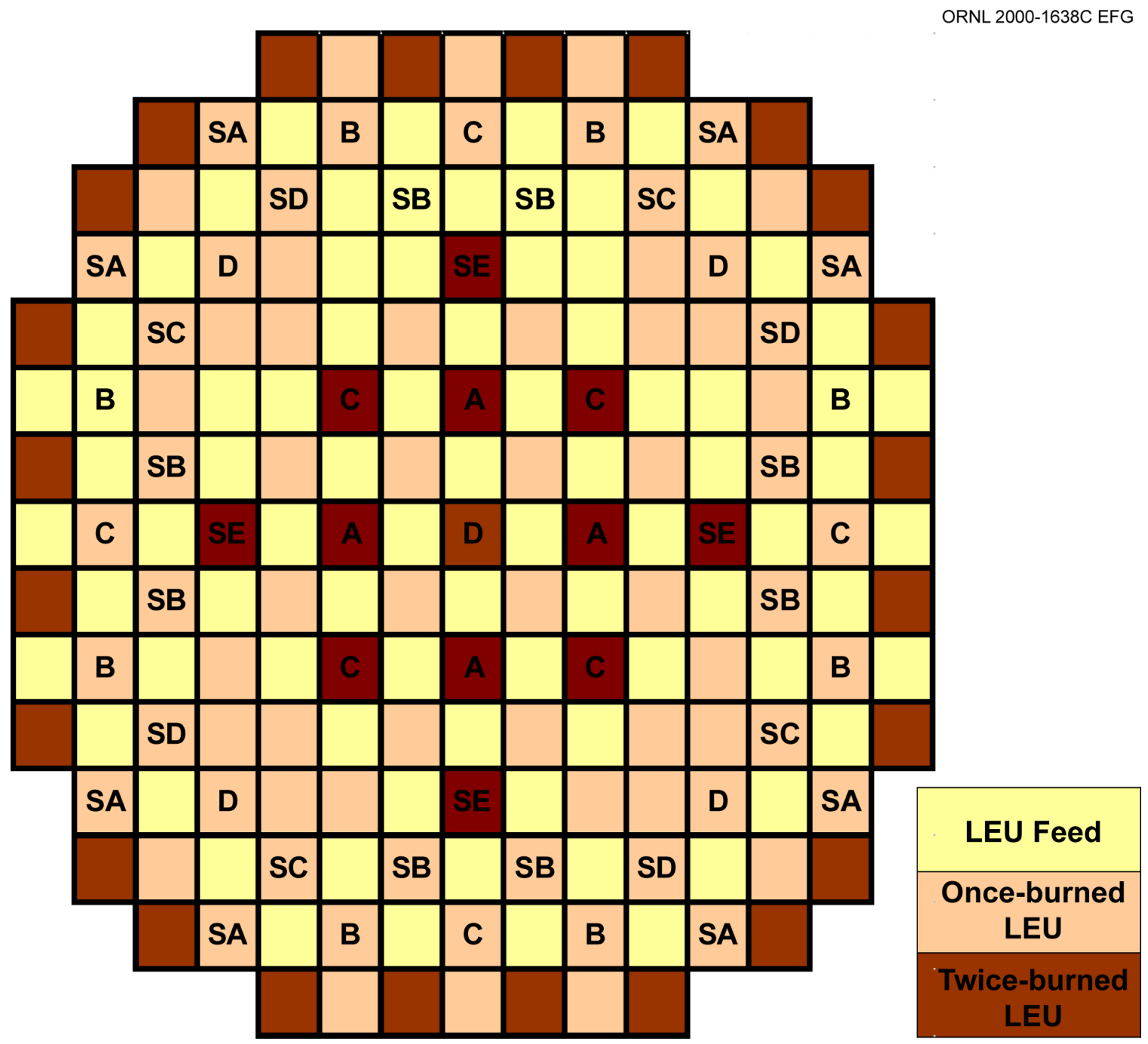

Figure 22. LEU equilibrium fuel-loading pattern. 


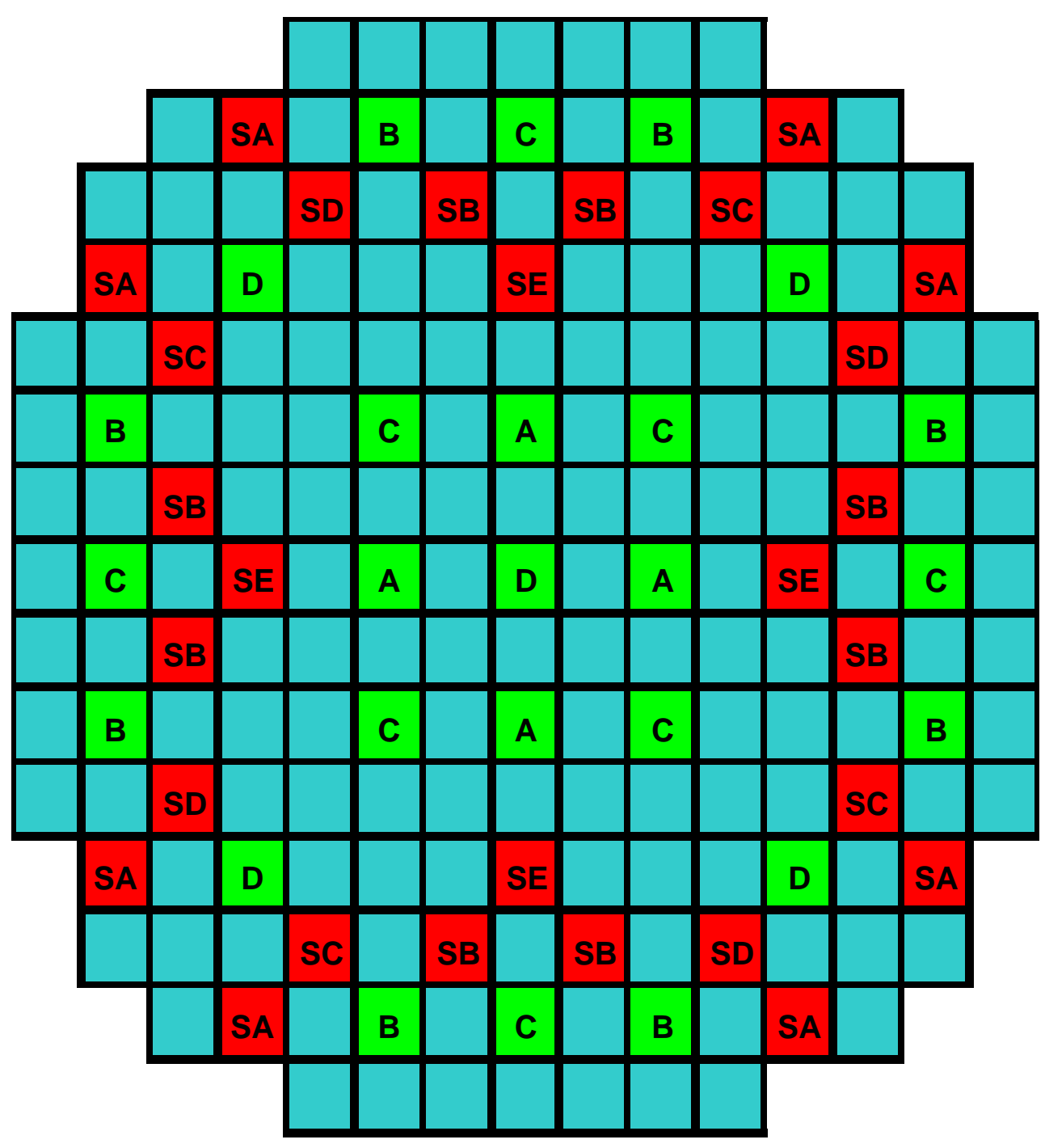

\begin{tabular}{|c|c|c|c|}
\hline Control banks & Number of rods & Shutdown banks & Number of rods \\
\hline A & 4 & SA & 8 \\
\hline B & 8 & SB & 8 \\
\hline C & 8 & SC & 4 \\
\hline D & 5 & SD & 4 \\
\hline Total & 25 & SE & 4 \\
\hline \multicolumn{2}{r|}{ Total } & $\mathbf{2 8}$ \\
\cline { 2 - 4 }
\end{tabular}

Figure 23. Location of shutdown and control rod clusters in Catawba Units 1 and 2.

The DCS fuel management strategy encompasses the following constraints, limits, and details:

- 18-month fuel cycles, which are consistent with the LEU situation

- fuel pins for MOX and LEU with cladding OD of $0.374 \mathrm{in} .(0.950 \mathrm{~cm})$-this is consistent with current LEU fuel pins

- MOX fuel assembly consistent with current LEU designs 
- MOX fuel burnup limit of 45,000 MWd/MTHM (assembly average) with 50,000 MWd/MTHM (rod) - consistent with Framatome experience

- LEU rod burnup limit of 60,000 MWd/MTU—consistent with current LEU limits

- 35 to $40 \%$ MOX fuel core fractions

- MOX fuel will have two cycles of irradiation

- LEU fuel will have three cycles of irradiation

- only three enrichment zones in MOX fuel

- only four different plutonium enrichments from the MOX fabrication plant

- MOX fuel power peaking consistent with LEU fuel peaking and core limits

- "low-leakage" core design

- no integral absorbers in the MOX fuel

The DCS feasibility studies have shown that acceptable transition and equilibrium core designs can be attained for the mission reactors using just two MOX fuel assembly average enrichments. Acceptable loading patterns were modeled using average MOX fuel levels of 4.07 and $4.37 \mathrm{wt} \%$ plutonium and LEU fuel enriched to levels needed to reach the desired fuel cycle duration. Multiple enrichments of LEU fuel in conjunction with appropriate placement of the MOX fuel and the use of BP rods were used in DCS modeling to shape the radial power distribution and control the power peaking.

Some details of the DCS fuel-loading strategy are as follows:

- Loading feed MOX fuel is near the core exterior.

- Once-burned MOX fuel is loaded more toward the interior of the core.

- The designs minimize the placement of MOX fuel in locations with control rods to minimize reductions in control rod worth and shutdown margins.

- Designs minimize placement of MOX fuel on the core periphery.

Equilibrium partial MOX fuel core designs require the use of large numbers of BPRs for controlling power peaking and to reduce beginning-of-core (BOC) soluble boron concentration requirements. The necessary increase in BP requirements is the result of the decreased efficiency of thermal absorbers. DCS core designs used the FCF BP assembly design to control power peaking. This design was chosen because the ${ }^{10} \mathrm{~B}$ content of the BPRs and the number of BPRs per assembly could be varied.

The harder neutron spectrum associated with MOX fuel decreases the efficiency of thermal neutron absorbers; therefore, it increases the BOC soluble-boron requirements for partial MOX fuel cores compared to those for LEU cores (for both operating and accident situations). Because of reactor coolant system chemistry considerations, there is an upper limit to BOC boron concentrations. The use of additional BPR (above what is needed to control peaking) and the use of enriched soluble boron can reduce the boron concentration requirements to more reasonable levels. The use of additional BPRs results in an economic penalty, and the use of boron enriched in ${ }^{10} \mathrm{~B}$ to $25 \%$ or more adds cost because it is more expensive than natural boron.

The harder spectrum and the reduced thermal neutron flux in the MOX cores reduces the control rod worth. The Catawba reactors use a hybrid $\mathrm{B}_{4} \mathrm{C}$ control rod design, mostly $\mathrm{B}_{4} \mathrm{C}$ with a 40 -in. (101.6-cm) $\mathrm{Ag}-\mathrm{In}-\mathrm{Cd}$ tip. This hybrid $\mathrm{B}_{4} \mathrm{C}$ control rod absorber design is more effective than the full Ag-In-Cd design; the reactivity worth is about $0.2 \% \Delta \mathrm{k} / \mathrm{k}$ at the end of cycle.

\section{SUMMARY AND CONCLUSION}

Duke Power's four Catawba and McGuire PWRs are to be used by DCS for weapons-grade plutonium disposition. Computer models representing the Catawba and McGuire reactor cores and assemblies have been developed based on the information and assumptions presented as data in this document. The results of fuel-management and core-loading calculations for these reactors will be presented in a later report. 


\section{REFERENCES}

1. Updated Final Safety Analysis Report-Catawba Nuclear Station Units 1 \& 2, May 1997.

2. Westinghouse Electric Corporation, Plutonium Disposition Study: Implementation of Weapons Grade MOX Fuel in Existing Pressurized Water Reactors, DOE/SF/19683-7, August 1996.

3. G. Alonso-Vargas and M. L. Adams, Studies of Flexible MOX/LEU Fuel Cycles, ORNL/SUB/ 99-19XSY062V-1, ANRCP-1999-1, March 1999.

4. DCS/ORNL Physics Meeting, DCS Headquarters, Charlotte, North Carolina, January 14, 2000. 
Page Intentionally Blank 
ORNL/TM-1999/255

\section{INTERNAL DISTRIBUTION}

$\begin{aligned} 1-5 . & \text { R. J. Ellis } \\ 6 . & \text { J. C. Gehin } \\ 7 . & \text { S. R. Greene } \\ 8 . & \text { D. T. Ingersoll } \\ 9 . & \text { M. A. Kuliasha } \\ 10 . & \text { G. E. Michaels } \\ 11 . & \text { L. J. Ott } \\ 12-16 . & \text { R. T. Primm III }\end{aligned}$

17. C. C. Southmayd

18. D. J. Spellman

19. D. L. Williams, Jr.

20. K. A. Williams

21. Central Research Library

22-23. ORNL Laboratory Records (OSTI)

24. ORNL Laboratory Records-RC

\section{EXTERNAL DISTRIBUTION}

25. M. L. Adams, Department of Nuclear Engineering, Texas A\&M University, Zachry 129, College Station, TX 77843

26. D. Alberstein, Los Alamos National Laboratory, MS-K551, P.O. Box 1663, Los Alamos, NM 87545

27. K. Chidester, Los Alamos National Laboratory, MS-E502, P.O. Box 1663, Los Alamos, NM 87545

28. R. H. Clark, Duke Power, 400 South Tyron Street, WC32, P.O. Box 1004, Charlotte, NC 28202

29. W. Danker, U.S. Department of Energy, MD-3, 1000 Independence Avenue SW, Washington, DC 20585

30. J. L. Eller, Duke Power, 526 South Church Street, ECO8G, Charlotte, NC 28202

31. L. Holgate, Office of Fissile Materials Disposition, U.S. Department of Energy, NN-60, 1000 Independence Avenue SW, Washington, DC 20585

32. L. Losh, 3315 Old Forest Road, P.O. Box 10935, Lynchburg, VA 24502

33. S. P. Nesbit, Duke Power, 400 South Tyron Street, WC32, P.O. Box 1004, Charlotte, NC 28202

34. J. O. Nulton, Office of Fissile Materials Disposition, U.S. Department of Energy, NN-61, 1000 Independence Avenue SW, Washington, DC 20585

35. S. L. Passman, Booz-Allen \& Hamilton, 555 13th Street NW, No. 480E, Washington, DC 20004

36. P. T. Rhoads, Office of Fissile Materials Disposition, U.S. Department of Energy, NN-61, 1000 Independence Avenue SW, Washington, DC 20585

37. J. Thompson, Office of Fissile Materials Disposition, U.S. Department of Energy, NN-61, 1000 Independence Avenue SW, Washington, DC 20585

38. F. Trumble, Westinghouse Savannah River Company, Building 730R, Room 3402, Aiken, SC 29808

39. M. S. Chatterton, Office of Nuclear Reactor Regulation, MS O10B3, United States Nuclear Regulatory Commission, Washington, DC 20555-0001

40. R. W. Lee, Office of Nuclear Reactor Regulation, MS O10B3, United States Nuclear Regulatory Commission, Washington, DC 20555-0001

41. U. Shoop, Office of Nuclear Reactor Regulation, MS O10B3, United States Nuclear Regulatory Commission, Washington, DC 20555-0001

42. E. Siskin, Office of Fissile Materials Disposition, U.S. Department of Energy, NN-60, 1000 Independence Avenue SW, Washington, DC 20585 